
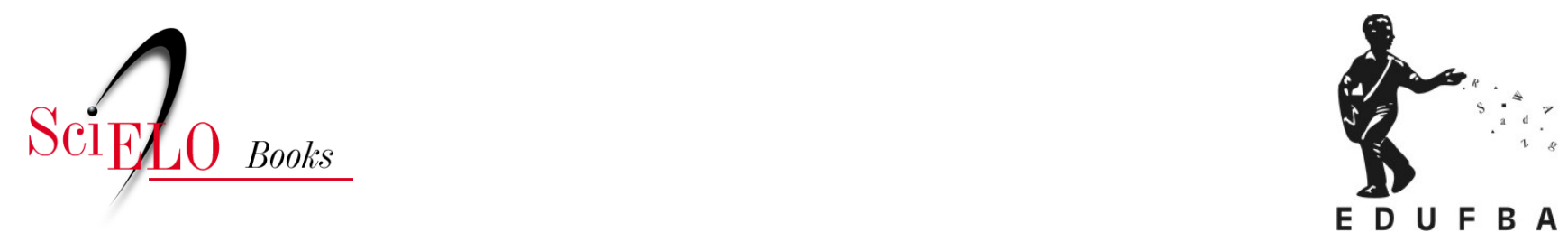

\title{
O vício contra a civilização pretendida patologizando um hábito, criminalizando uma prática
}

\author{
Jorge Emanuel Luz de Souza
}

\section{SciELO Books / SciELO Livros / SciELO Libros}

SOUZA, J.E.L.S. O vício contra a civilização pretendida: patologizando um hábito, criminalizando uma prática. In: Sonhos da diamba, controles do cotidiano: uma história da criminalização da maconha no Brasil republicano [online]. Salvador: EDUFBA: CETAD/UFBA, 2015, pp. 33-89. Drogas: clínica e cultura collection. ISBN: 978-85-232-2023-5. https://doi.org/10.7476/9788523220235.0004.

All the contents of this work, except where otherwise noted, is licensed under a Creative Commons Attribution 4.0 International license.

Todo o conteúdo deste trabalho, exceto quando houver ressalva, é publicado sob a licença Creative Commons Atribição 4.0. 


\section{O VÍCIO CONTRA A CIVILIZACSÃO PRETENOIDA: PATOLOGIZANOO UM HÁBITO. CRIMINALIZANDO UMA PRÁTICA}

Em seu gabinete no Palácio do Itamaraty no Rio de Janeiro, no dia 24 de agosto de 1938, o Ministro das Relações Exteriores, Oswaldo Aranha, encaminha a Getúlio Vargas um ofício. Seguia em anexo o anteprojeto do que viria a ser alguns meses depois o Decreto-Lei n. ${ }^{891}$, a norma jurídica mais abrangente sobre controle e repressão ao uso psicoativo de drogas no Brasil até então. Afim de "habilitar" o presidente a "resolver sobre a aprovação" do respectivo anteprojeto, Aranha faz uma apresentação geral do texto explicando seus capítulos.

Ao tratar do capítulo III, dedicado à questão da saúde pública, destaca a centralidade da "internação" e da "interdição civil" do usuário de drogas, assim como a proibição do "tratamento de toxicômanos em domicílio" como formas de lidar com o fenômeno. Então, prossegue de forma esclarecedora a explanação:

A internação far-se-á, obrigatória ou facultativamente, em estabelecimentos oficiais ou particulares sujeitos à fiscalização oficial. Cabe aqui o reparo de que, sendo reduzidíssimas as instalações dos estabelecimentos oficiais destinados aos toxicômanos e sendo igualmente pequeno o número de hospitais particulares habilitados a aceitar tais doentes, nas condições legais, seria de toda conveni- 
Sonhos da diamba

ência que o Governo aproveitasse um ou mais pavilhões da Colônia de Psicopatas de Jacarepaguá para esse fim. (BRASIL, 1938a, p. 2, grifo nosso)

O anteprojeto foi elaborado pela Comissão Nacional de Fiscalização de Entorpecentes (CNFE), criada dois anos antes, e nas palavras do próprio ministro, a proposta seria uma "consolidação da legislação existente sobre a matéria" acrescida de dispositivos que visavam atualizar o país na questão.

Evidencia-se que a visão médica predominante à época sobre o consumo de drogas guiava os elaboradores do anteprojeto e, de maneira ampla, representava a tônica das ações do poder público nesse campo. O anteprojeto, mantido no Decreto-Lei a que deu origem quase integralmente, deixa clara a forma escolhida pelo Estado para lidar com os indivíduos que consumiam as substâncias proibidas: o confinamento, a "internação".

Proibindo qualquer forma de "tratamento em domicílio", materializava-se a "interdição civil" dos sujeitos e garantia-se ao Estado a exclusividade na gerência do "problema da toxicomania”. Isso parecia ser fundamental nessa forma de administrar a questão ainda que o Estado não estivesse suficientemente preparado, pois eram "reduzidíssimas as instalações" públicas ou mesmo as particulares. Os usuários eram "doentes" que poderiam ser encarcerados numa "colônia de psicopatas", como se verá, mais um ponto central da perspectiva médica: a droga causadora de loucura.

A medicina no Brasil fornecia a base teórica e sugeria os mecanismos para a intervenção, por parte do Estado, em parcelas cada vez maiores da população, sobretudo das classes subalternas. Essa imbricação de interesses não se deu de maneira tão profunda desde sempre e os médicos travaram duras batalhas desde o século XIX para gozar de tal posição perante 
a sociedade. (SAMPAIO, 2001) Foi na década de 1930 que se ampliou e consolidou a presença da classe médica dentro do aparelho de Estado. O desaparecimento das ligas eugênicas e de higiene mental, comuns na década anterior, por exemplo, se deveu à concretização de suas propostas, levando a uma realocação desses profissionais dentro do poder público através da criação de órgãos técnicos. (CUNHA, 1986) É inegável que naqueles fins da década de 1930 e no que diz respeito ao consumo de drogas, definiam a postura oficial de repressão, em parte também ditada pelas proposições da Liga das Nações.

O consumo de substâncias psicoativas passaria a significar "toxicomania" na perspectiva médica brasileira na virada para o século XX, algum tempo depois desse movimento se generalizar na Europa. A toxicomania passou a integrar - ao lado da sexualidade, do trabalho e do lazer - um repertório de questões visadas pela medicina que apontavam cada vez mais para as práticas coletivas, eram captadas em todas as esferas da vida social e pensadas com base nas teorias da raça, da degenerescência e da eugenia. (COSTA, 1995; CUNHA, 1986)

A maconha não escapou a esse processo de crescente "medicalização" da sociedade, pois coube a um médico - Rodrigues Dória -, em 1915, o primeiro passo para transformar os usos da planta num "problema social". Não por acaso, esse médico era professor da Faculdade de Medicina da Bahia (FMB) e formulou suas teses contra a maconha nas duas primeiras décadas do século passado, um contexto bem específico e conflituoso de reestruturação da sociedade local e nacional.

Foi esse discurso de um grupo social cujo projeto de poder triunfava que fundamentou a criminalização de determinadas drogas e incentivou a produção em larga escala de outras. O discurso médico foi a base sobre a qual se desenvolveu o proibicionismo mundial e brasileiro das drogas no século XX. 
A criminalização no Brasil, iniciada em 1921 com o Decreto n. 4.294, que se ocupou apenas da cocaina, do ópio e da morfina, tem seu desdobramento mais amplo em 1938, com o Decreto-Lei n. ${ }^{\circ} 891$, intitulado Lei de Fiscalização de Entorpecentes. Seu raio de ação foi estendido a dezenove substâncias, entre elas a maconha, que já havia sido inserida na lista oficial proibitiva do Decreto n. 20.930 em 1932. A transformação da maconha em "problema público" foi precedida da sua transformação em "problema médico". Mas quase duas décadas separaram uma e outra forma de construção do "problema". As próximas páginas tentarão compreender como esses processos se articularam, como a condenação médica encontrou um contexto sensível à aceitação dessas ideias pelo Estado durante a década de 1930.

Para tanto, serão seguidas pistas que levam a um ponto de partida ainda na década de 1910. Mais precisamente, o ano é 1915 e a ocasião o II Congresso Científico Pan-Americano, realizado em Washington nos Estados Unidos. Nele representava o governo do estado da Bahia, a Faculdade de Direito, a Faculdade de Medicina, o Instituto Geográfico e Histórico da Bahia e a Sociedade de Medicina Legal e Psiquiatria da Bahia o médico José Rodrigues da Costa Dória. Natural de Sergipe, Dória doutorou-se na FMB em 1882, assumindo a cadeira de medicina legal e toxicologia na mesma instituição em 1885. Foi aluno de Nina Rodrigues e teve vida politica ativa, ${ }^{1}$ sendo eleito deputado federal em 1897, renovando sucessivas vezes o mandato até 1908 quando assumiu a presidência do seu estado natal, cargo que ocupou até 1911. (OLIVEIRA, 1992)

1 Havia nesse contexto a ideia de uma "vocação política" natural na carreira médica, assim como na magistratura, por isso os filhos das famílias mais abastadas e com tradição política eram enviados para estudar em instituições como a Faculdade de Medicina da Bahia. (COSTA, 1997) 
Dória viajou aos Estados Unidos em dezembro de 1915 para apresentar o trabalho que se tornou a principal referência do proibicionismo da maconha no Brasil: "Os fumadores de maconha: efeitos e males do vício". (1958, p. 1-14) Seu trabalho colocou as linhas gerais do discurso condenatório da maconha absorvido cada vez mais por cientistas, imprensa e autoridades: o enquadramento do hábito na categoria de "toxicomania", a acusação das classes subalternas como consumidoras exclusivas da erva e a dimensão racial do uso de maconha no Brasil. O nome de Rodrigues Dória seria presença absoluta na produção sobre o assunto nas décadas seguintes e suas teses seriam invariavelmente repetidas até meados da década de 1960.

O médico já havia demonstrado atenção com o consumo de substâncias psicoativas anteriormente num artigo intitulado "Toxemia e crime", de 1907, mas foi em "Os fumadores de maconha" que ele delineou mais nitidamente o objeto de suas investidas e contribuiu de forma decisiva para sua repressão no Brasil. Para Dória (1958, p. 1-2) o hábito de fumar maconha era uma "toxicomania": um "vício pernicioso e degenerativo" capaz de causar "o delírio, a loucura transitória e mesmo definitiva”. Os usuários, sob seu efeito, "tornam-se rixosos, agressivos, e vão até a prática de violências e crimes". (1958, p. 7) Por ser um "vício imperioso, dominante e tirânico", para os "[...] fumadores de maconha [...] quase sempre a morte sobrevém em pouco tempo". (1958, p. 9)

"Vício" para Dória possuía um sentido bem próprio. A "doença do vício" surge nos debates acerca da questão do consumo de psicoativos no interior das disciplinas médicas na Europa do século XIX, tendo Thomas Trotter, Esquirol, Legrain e Morel como alguns dos maiores expoentes. (CARNEIRO, 2002b) A "embriaguês pelo álcool" foi o primeiro objeto dessa perspectiva, tomando-a inicialmente como uma "doença da mente" até 
considerá-la uma “degeneração hereditária”. (COSTA, 1997, p. 69) Logo, outras substâncias entrariam em cena, tais como o ópio e o haxixe, um derivado da planta Cannabis sativa, drogas de amplo consumo à época no continente. Dessa forma, se desenvolve a noção mais abrangente de "toxicomania", como uma "entidade clínica autônoma", com base, entre outros, nos trabalhos de Moreau de Tours em 1845 e Emanuel Régis em 1885. (CARNEIRO, 2002b)

Para tanto, também era preciso construir uma ideia de substância psicoativa que homogeneizasse as diferenças entre as experiências individuais. Assim, a "substância tóxica", o "veneno social", o "estupefaciente", o "entorpecente" e, por fim, a "droga" passa a ser considerada como portadora de poderes químicos totais sobre o sujeito e, invariavelmente, o levaria à degradação. (CARNEIRO, 2002b) Os efeitos seriam os mesmos em todos, independentemente da singularidade dos sistemas biológicos, e as suas consequências seriam danosas não apenas ao organismo individual dos sujeitos, mas sim a todo o "organismo social", bem a par das teorias organicistas do período. O uso contínuo da substância seria uma das causas sociais da "loucura", pois seria transmitida do usuário aos seus descendentes, como pregavam as teorias da "degeneração hereditária".

Percebe-se que Dória estava em plena sintonia com as proposições da sua classe: ele fala em "vício degenerativo", "imperioso, dominante e tirânico" que espalhava hereditariamente "o delírio e a loucura", multiplicando "práticas violentas e crimes" até a "morte em pouco tempo". Ao focalizar o uso psicoativo de maconha, o médico o apresenta enquadrado nas categorias de "vício", "toxicomania" e "entorpecente", imprimindo no hábito as correlatas noções de "degeneração", "loucura" e "tirania" da substância química. Não se pode esquecer que 
Dória era professor de Toxicologia na Faculdade de Medicina da Bahia, instituição de prestígio nacional e um dos centros difusores das teorias da medicina social no Brasil naquele início de século XX. (SCHWARCZ, 2001)

Outra tese importante para a criminalização da maconha foi desenvolvida nas páginas do artigo de 1915. Foi Rodrigues Dória o primeiro a tomar como predominante no Brasil o consumo de maconha que havia entre as classes trabalhadoras. Ele viveu boa parte da vida em sua cidade natal, Propriá, no interior de Sergipe, onde afirmou haver um uso bastante difundido em "bordéis", "quartéis", "prisões" e nas "feiras semanais". Com base em observações feitas em Sergipe, além de Salvador e no Rio de Janeiro, foi o pioneiro na associação que se tornou inseparável no discurso e prática da repressão à maconha, a de que seu uso psicoativo era uma exclusividade de "pessoas de baixa condição". Localizando-as "principalmente no norte do Brasil", Dória (1958, p. 2) afirmou: “[...] é nas camadas mais baixas que predomina o seu uso, pouco ou quase nada conhecido na parte mais educada e civilizada da sociedade brasileira".

Para o professor de toxicologia eram "analfabetos", "homens do campo", "canoeiros", "pescadores", enfim, todos os grupos que considerava a "escória da nossa sociedade". Nesses "estados do norte", dizia ocorrer com frequência "violências cometidas durante a embriaguez da maconha". (DÓRIA, 1958, p. 12) Esse perfil de classe definido pelo médico em relação ao consumo de maconha também foi bastante reproduzido e explorado tanto pelos especialistas que escreveram sobre a questão quanto pelas autoridades que foram imbuídas da repressão. Se vasculhada a bibliografia produzida entre as décadas de 1930 e 1940, por exemplo, período de maior produção científica sobre a maconha na primeira metade do século XX, é encontrada com facilidade a relação maconha-pobres (negros 
e pardos - Norte/Nordeste). Bem como, se observarmos as fontes será possivel perceber o quanto a ação dos agentes legais foi voltada para locais de ajuntamento, trabalho e divertimento populares.

A terceira tese do artigo é a racialização do "problema da maconha". Nesse ponto ele desdobra o argumento em dois sentidos: a origem africana da maconha no Brasil e a "vingança da raça inferior". No primeiro ponto, Dória busca estabelecer, a partir das referências de Bentley e Charles Eloy, a procedência da planta que ele atribui ser resultado do tráfico de escravos:

A planta não é, entretanto brasileira, como pensam os primeiros lexicógrafos [...], o fato de ser vegetal largamente usado pelos pretos africanos, nas antigas províncias, hoje Estados, onde eles abundavam, a paridade dos nomes que aqui sofreu ligeira modificação, mudança de apenas uma letra - maconha, liamba ou riamba - e o apelido de fumo d'Angola, indicam bem a sua [importação africana]. (DÓRIA, 1958, p. 2)

No segundo sentido, toma de empréstimo a proposição de Emanuel Régis sobre uma das consequências das Guerras do Ópio entre a Inglaterra e a China no século XIX, vencidas pelos britânicos. (LOVELL, 2011) Essa teria sido a adoção do consumo da droga pelos "brancos civilizados", ou seja, "o vencido que se vinga do vencedor" e, com isso, afirma:

A [raça preta], selvagem e ignorante, resistente, mas intemperante, prestou grandes serviços aos brancos, seus irmãos mais adiantados em civilização [...] e inoculou também o mal a maconha nos que a afastaram da terra querida, the roubaram a liberdade preciosa e lhe sugaram a seiva reconstrutiva. (DÓRIA, 1958, p. 13)

O artigo de Rodrigues Dória opera uma "valoração racial da maconha", relacionando as características negativas atribuídas por ele à "raça negra" às da planta com o objetivo de 
naturalizar o "problema". Sendo assim, do lado da "raça" ele elenca "ignorância", "resistência", "intemperança", "fetichismo" e "agressividade", enquanto que da maconha tem-se "degeneração", "analgesia", "vício", "loucura" e "crime". (ADIALA, 1986) Para ele, indubitavelmente, era fruto de "importação africana", era mesmo "vegetal largamente usado pelos pretos africanos" no seu continente de origem. Como uma forma de "vingança do vencido" por ter sido escravizado, o negro, que ele considerava "a raça inferior", teria introduzido a maconha, "o mal", na sociedade dos brancos, para ele, "mais adiantados em civilização".

Quando escreveu "Os fumadores de maconha" em 1915, Dória já contava mais de 30 anos vivendo entre Salvador, onde era professor das Faculdades de Medicina e Direito, Sergipe, estado pelo qual exerceu carreira política entre 1897 e 1911, e Rio de Janeiro, já que era deputado federal. Na Bahia, era a primeira gestão do governador J. J. Seabra (1912 - 1916), que se notabilizou, em tempos de inúmeras intervenções urbanísticas, pelo esforço em dar à capital "foros de civilização". (LEITE, 1996) Na Bahia, onde existia uma das maiores populações negras do Brasil, ainda vivia-se intensa mobilidade de indivíduos egressos da escravidão e seus descendentes para cidades que representavam pólos atrativos, como Salvador, o que fortalecia os temores das elites locais de ameaças à ordem diante do esgotamento das formas senhoriais de controle. Como se sabe, a noção de raça assumiu função de destaque nesse contexto. (ALBUQUERQUE, 2009; FRAGA FILHO, 2006; OLIVEIRA, 2010)

Dória tem como base primordial para essa tese, as teorias deterministas do evolucionismo social e do racismo científico, que dividia a humanidade em etapas inspiradas no modelo das ciências naturais e postulava a superioridade e a inferioridade das "raças", relegando para negros e mestiços os niveis mais 
baixos dessa hierarquia. Essas ideias alcançaram o Brasil de forma significativa nos fins do século XIX, momento de redefinição dos projetos de nação, instituindo critérios de diferenciação baseados na noção de "raça", legitimando a manutenção das antigas hierarquias sociais, bem como definindo uma excludente cidadania republicana. (ALBUQUERQUE, 2009; GUIMARÃES, 2002; SCHWARCZ, 2001)

O que faz Dória em "Os fumadores de maconha” é equacionar, com base nos valores da sua classe e nas categorias da sua ciência, um problema real que vinha sendo colocado às classes dominantes no início da república: com o fim, ao menos institucional, das tecnologias de controle da escravidão que perduraram por séculos no Brasil, era preciso que fossem estabelecidas novas formas capazes de manter sob vigilância aqueles que deveriam permanecer excluídos. Cumprindo o seu papel de médico membro da elite política regional no início do século XX, Rodrigues Dória se voltou para o uso psicoativo da maconha informado por questões que em muito ultrapassavam a pretensa neutralidade científica da medicina e o seu objetivo declarado. Ao relacionar maconha e raça respondia a questões específicas do contexto social baiano e brasileiro, postas pela dinâmica histórica aos grupos que pretendiam reestruturar a sociedade sem alterar as antigas posições e normas que os mantinham hegemônicos. ${ }^{2}$

Rodrigues Dória (1958, p. 10-12) ainda vai além, sugerindo a "proibição do comércio da planta" como forma de "restringir a sua disseminação progressiva". Interpreta o parágrafo 4 do artigo 27 do Código Penal de 1890, em voga na época, para considerar a existência de culpa dos que praticassem crimes

2 Os médicos eram um grupo social bem situado na sociedade e na máquina estatal baiana, pois, segundo dados compilados por Consuelo Novais Sampaio, eram o segundo maior grupo de poder dentro do aparelho de Estado durante a Primeira República. (SAMPAIO, 1985) 
no "estado de embriaguez pela maconha", visto que a "escusa do crime" não se aplicaria quando a embriaguez fosse "procurada", apenas quando fosse "acidental". Na sua lógica, como os usuários de maconha a fumavam intencionalmente, não poderiam ser beneficiados pela "escusa da privação de sentidos".

De uma só vez naturalizou o "problema”, elegeu um culpado, sugeriu uma solução repressiva e apresentou um caminho legal para o acesso a esses indivíduos. ${ }^{3}$ Em outras palavras, Dória diz que reprimir os usos da maconha poderia ser transformado em eficiente instrumento de controle das classes subalternas na Bahia, mais especificamente de negros e mestiços, grupos sociais que por sua trajetória histórica vinham sendo considerados em todo o país como as "classes perigosas". Entretanto, o médico não veria materializado automaticamente seu objetivo. Passaram-se quase duas décadas até que as autoridades públicas se apropriassem do "problema" enunciado pelos médicos. Somente em 1932, dezessete anos após o artigo, a maconha será alvo de regulação legal no Brasil.

É de fundamental importância averiguar esse processo que parte da década de 1910, contexto no qual permaneceu uma ausência geral de especialização jurídica da questão das drogas, e chega à década de 1930, onde a intervenção do Estado se estabelece em definitivo. Será preciso compreender quais as mudanças históricas que desembocaram nos anos de 1930, a década das proibições, e definiram as condições ideais para

3 Como médico, o dr. Rodrigues Dória, atuou na questão como um "empresário moral", interpretando um determinado fenômeno, através de um forte apelo a questões sensiveis do seu contexto, à luz do referencial da sua classe e sugerindo também as medidas de repressão e controle. Como era membro de um grupo de prestígio na sua sociedade, sentia-se legitimado para expressar a sua perspectiva e pressionar outros grupos sociais a se aliarem à sua causa, construindo um "problema social". (BECKER, 2009b; LENOIR, 1998) 
Sonhos da diamba

essa base ideológica fornecida pela medicina servir de fundamento às práticas do proibicionismo brasileiro.

Ausência de especialização, entretanto, não quer dizer que nada foi feito oficialmente na década de 1910 em relação ao uso de drogas. O Estado se deteve em três substâncias: o ópio, a morfina e a cocaina. Com o Decreto n. 2.861 de 8 de julho de 1914, sancionou a Convenção Internacional do Ópio realizada em Haia em 1912 e determinou, com o Decreto n. 11.481 de 10 de fevereiro de 1915, uma maior observância das proposições da Convenção de Haia pelas autoridades nacionais em vista do "abuso crescente" do seu consumo. (SILVA, 2011) Como se vê, no mesmo ano em que Dória escolhia a maconha como o mais perigoso dos entorpecentes, o presidente Wenceslau Braz apontava para outros.

Levando em conta que o Brasil ainda não frequentava esses fóruns internacionais acerca dos usos e comércio dos psicoativos, não sendo um especialista nas discussões é plausível supor que a ratificação da Convenção de Haia de 1912 se tratasse mais de política externa que de uma efetiva preocupação estatal com o consumo de drogas. Sancionar tratados internacionais é indispensável como politica de aproximação e formação de alianças entre os países. Ainda que não se possa negligenciar a existência de tal preocupação, é indicativo desse ponto de vista o fato do governo meramente confirmar as orientações da Convenção Internacional ao invés criar uma lei própria nacional. Medida efetiva na direção de uma restrição legal a substâncias específicas foi tomada somente 1921 .

O passo mais firme na esteira do proibicionismo na Primeira República foi dado nos anos 1920: o Decreto n. 4.294 de 6 de julho de 1921. Este definia as drogas como "substâncias venenosas", a mesma nomenclatura empregada pelo Código Penal de 1890. A partir de então, a cocaína, o ópio e um dos 
seus derivados, a morfina, só poderiam ser vendidos, expostos ou ministrados com "legitima autorização" de acordo com as "formalidades prescritas nos regulamentos sanitários". (BRASIL, 1921a, p. 1) Com isso se buscava controlar pela via jurídica e médica a circulação e o consumo dessas substâncias. A partir de então se criava um novo tipo de crime, o "uso ilícito" das drogas. Criava-se também um novo tipo de criminoso: o indivíduo que vendesse, guardasse ou usasse as "substâncias venenosas" sem autorização médica. Esse último era reconhecido pelo termo "intoxicado", um misto de doente e criminoso, sendo o equivalente jurídico do "toxicômano" dos médicos.

$\mathrm{Na}$ outra ponta, o Decreto estabelecia as formas de tratamento e penalidades para os "intoxicados": determinava a criação de "estabelecimento especial para internação", no qual deveria ter um "regime de trabalho". Isso demonstra uma ideia comum no período, viva ainda hoje, de que o trabalho, como parte do "tratamento", é um meio "regenerador". A internação nesses estabelecimentos poderia ser de forma obrigatória, através de condenação por "embriaguez habitual" ou interdição civil, bem como de forma voluntária. Mais uma característica fundamental eram as penas previstas: multas que variavam de 100 réis a 1 conto de réis, fechamento de estabelecimentos comerciais, internação de três meses a um ano e prisão celular de um a quatro anos.

O Decreto n. 4.294 de 1921 revogou o artigo 159 do Código Penal de 1890, passando a ser a norma central a tratar da matéria das substâncias psicoativas no Brasil. Menos de dois meses depois, no dia 3 de setembro, seria aprovado o regulamento que buscava lhe dar funcionalidade por meio do Decreto $n .^{\circ} 14.969$. Contudo, o regulamento estendeu ainda mais o controle estatal nesse campo, dispondo também sobre a importação das substâncias, ponto silenciado no Decreto de julho. 
Sonhos da diamba

Um detalhe significativo no Decreto n. 14.969 foi a inclusão do termo "toxicômano", que não apareceu no anterior, o que parece indicar uma atualização médica do discurso jurídico.

Entretanto, mesmo tendo sido a maconha um dos primeiros objetos da investida médica contra as drogas ambos os Decretos não dispõem sobre ela, apenas sobre o ópio, a morfina e a cocaína. Essas eram, em geral, as drogas das elites, consumidas em meetings, bailes, cabarés e cafés por intelectuais, moços e moças abastados e artistas, constituindo-se em parte fundamental de um modo de vida inspirado nas metrópoles europeias, sobretudo Paris. Eram vendidas livremente nas farmácias, propagandeadas em jornais e receitadas por médicos aos seus pacientes. (CARNEIRO, 1993) Por que no momento em que os médicos voltavam o foco para o consumo de maconha - droga das classes subalternas - o governo demonstrava preocupação com a circulação de entorpecentes entre as elites? A busca da resposta leva à singularidade da questão dos entorpecentes na década seguinte, a década de 1930, a Era Vargas.

Sem dúvidas, em relação ao controle do consumo de drogas no Brasil, as décadas de 1930 e 1940 foram um período de grande esforço normatizador. Durante os anos trinta, que podem ser conhecidos como a década das proibições ou década do proibicionismo, foram instituídas normas em 1932, 1936 e 1938 e ratificados tratados internacionais em 1934 e 1938. Cada vez mais amplos e restritivos aumentaram como nunca o poder do Estado dispor sobre a matéria. Inauguram-se órgãos especializados a exemplo da CNFE, além da determinação de criar as suas equivalentes regionais, as Comissões Estaduais de Fiscalização, que alcançaram efetivo funcionamento nos anos 1940 .

O intercâmbio internacional apresentou um fluxo até então inédito. O Brasil mandava agentes de repressão às drogas 
para outros países a fim de atualizar conhecimentos sobre o assunto, participava de conferências, trocava correspondências e enviava relatórios com a mesma frequência que recebia de outras nações. Isso nos leva a crer que algo havia mudado na realidade social e interferido na forma com que o Estado vinha lidando com as drogas e seus usuários até então. Foi nesse período que a maconha passou a ser substância proscrita no Brasil desde a primeira lei de drogas do governo Vargas em 1932.

Essa mudança foi dupla. No plano internacional, era o auge da mundialização da repressão ao consumo psicoativo de determinadas substâncias, liderada pela Liga das Nações e orientada sobretudo pelo modelo proibicionista que vinha sendo gestado pelo governo dos Estados Unidos. No plano interno, a mudança política trazida pelo movimento de 1930 no Brasil conduziu novos grupos sociais ao poder, dotados de novos interesses, objetivos e projetos para a nação. Possivelmente a postura oficial fosse outra se o contexto internacional não tivesse a criminalização e a repressão como perspectivas hegemônicas na gestão do fenômeno. Entretanto, isso não autoriza afirmar que o proibicionismo brasileiro das drogas foi uma mera importação de modelos externos.

Foi a confluência dessas duas dimensões que determinou os rumos do processo, pois era preciso que as diretrizes e estratégias experimentadas em outros países encontrassem um terreno fértil para o seu desenvolvimento no Brasil. Serão abordadas primeiro as relações de força que coordenavam o mecanismo no exterior para, a seguir, compreender como o Estado brasileiro o filtrou de modo singular. Tão singular que criminaliza a maconha no mesmo momento em que esta desaparece da lista internacional proibitiva da Liga das Nações, a partir da Convenção de Genebra de 1931, só retornando na 
Sonhos da diamba

Lista IV da Convenção Única sobre Entorpecentes realizada em Nova Iorque em 1961.

A consolidação do proibicionismo como tendência transnacional de gestão do fenômeno do consumo de drogas se deve, em grande parte, à atuação de um organismo político, a Liga das Nações. Também chamada Sociedade das Nações, foi criada em abril de 1919 após a Conferência de Paz de Paris como desdobramento da I Guerra Mundial. Tendo como objetivo arbitrar na resolução de conflitos internacionais, rapidamente estabeleceu como uma das suas prioridades o controle da produção e comércio internacional de substâncias psicoativas, herdando os instrumentos e debates estabelecidos anteriormente, sobretudo, na Convenção do Ópio de Haia em 1912. (ESCOHOTADO, 1989)

Com a Convenção de Genebra de 1925 é criado um órgão executivo, o Comitê Central Permanente do Ópio (CCPO), sediado nos Estados Unidos que visava facilitar a comunicação entre os países latino-americanos e a liga, sediada em Genebra, mas este acaba por centralizar ainda mais as deliberações politicas sobre as drogas no continente nas mãos da grande potência, o que contribuiu para a adoção generalizada do modelo repressivo. (ESCOHOTADO, 1989) Em 1946 dissolveu-se a liga e suas atividades e incumbências são transferidas à Organização das Nações Unidas (ONU), inclusive o controle internacional de drogas. (BRASIL, 1946)

A Liga das Nações atuava na questão das drogas por meio de convenções, que eram acordos subscritos pelos países membros derivados das conferências que realizava. Diversas conferências internacionais para limitar e controlar a produção, o tráfico e o consumo de drogas foram realizadas sob os auspí- 
cios da liga. ${ }^{4}$ Uma das mais importantes e que teve participação do Brasil foi a Conferência de Genebra de 1936. Projetada a partir de 1933 (BRASIL, 1934a), é convocada três anos depois com o objetivo de estabelecer uma nova convenção para "a repressão do tráfico ilícito de drogas nocivas”. (BRASIL, 1936a, p. 1) O presidente Vargas nomeou o Segundo Secretário Jorge Latour, delegado plenipotenciário do Brasil à Conferência Internacional. (BRASIL, 1936b) Latour era diplomata brasileiro em Varsóvia e, para a sorte do historiador, produziu um minucioso relatório sobre o fórum.

Numa prova de particular interesse na ocasião, o governo brasileiro preparou para Latour um conjunto de instruções a serem consideras pelo delegado ao aderir aos acordos de modo que não fossem de encontro ao interesse nacional. Entre as questões pontuadas no documento se percebe a preocupação com as "aplicações de penalidades" aos implicados no comércio proibido, com "medidas de repressão da toxicomania", com a cooperação entre "países de fronteira comum" e com a "[...] limitação da cultura de plantas de onde extraem entorpecentes ou [...] sirvam para determinar hábitos tóxicos". (BRASIL, $1936 b$, p. 1) É nesse último ponto que surge a preocupação das autoridades nacionais com a maconha. A instrução oficial sobre ele diz:

Medida básica [...] No Brasil existe em grande quantidade a Cannabis sativa ao norte do país, onde é conhecida sob os nomes vulgares de diamba, liamba, maconha e

4 Antes da criação da liga, ocorreram duas importantes conferências internacionais, a de Xangai, em 1909, e a de Haia, entre 1911 e 1912, que tiveram o ópio e seus derivados como focos especiais, mas não deixaram de estender as regulamentações a outras substâncias, como a cocaína. Após a formação da liga as duas conferências mais importantes até aquele momento foram realizadas em Genebra nos anos de 1925 e 1931. (ESCOHOTADO, 2004) 
outras denominações. Já estão sendo tomadas medidas para a destruição dessa planta [...] pois [o governo] vem verificando a tentativa de seu emprego como elemento de narcomania por indivíduos que dela se utilizam para fumar, em cigarros ou por meio de cachimbos especiais. (BRASIL, 1936b, p. 2, grifo do autor)

O principal órgão de repressão às drogas, a CNFE, que elaborou as instruções, demonstrou o quanto já orientava seus esforços para a investigação dos usos da maconha no Brasil. Conhecia "nomes vulgares" da erva, localizava regiões de cultivo e também conhecia técnicas de consumo. Para essas autoridades "limitar a cultura da planta" era uma "medida básica", assim como a sua "destruição". Não deixa de ganhar destaque os traços do discurso médico que condenava o uso de maconha: nas observações acima era considerada "elemento de narcomania”, ou seja, uma toxicomania.

Em verdade, essa discussão decorria de uma proposta apresentada pelo governo britânico à Liga das Nações naquele mesmo ano de 1936. O Comitê de peritos encarregado de elaborar o projeto da Convenção de Genebra inseriu uma cláusula que proibiria "toda a cultura, colheita e produção com o fim de obter entorpecentes", o que atingia as indústrias farmacêuticas alemã e britânica. O governo britânico, por sinal, também grande comprador de matérias-primas para a produção de drogas farmacêuticas (SCHEERER, 1993), alegou que não se poderia incluir tal dispositivo no projeto da convenção sem conhecer de antemão a opinião dos diversos países produtores. Diante disso, solicitou à Liga que questionasse os governos nacionais sobre a concordância e possiveis observações à cláusula, devendo ser remetidas as respostas antes da Conferência em Genebra. (BRASIL, 1936c)

No dia 7 de abril de 1936 foi enviada ao Secretário Geral da Liga das Nações, Joseph Avenol, a resposta do Brasil com a 
aquiescência dos ministros das Relações Exteriores, José Carlos de Macedo Soares, e da Educação e Saúde, Gustavo Capanema: "o Governo brasileiro é inteiramente favorável à adoção desse dispositivo [...]”. (BRASIL, 1936d, p. 2) A concordância do Brasil foi então registrada na convocatória da Conferência de 1936, destacando o motivo primordial que levava àquele posicionamento: “[...] existe no Brasil, naturalmente, uma grande quantidade de diamba (Cannabis indica ou Cannabis sativa) cujo emprego está se espalhando". (BRASIL, 1936a, p. 2, grifo do autor) Fica evidente o quanto havia mudado a atitude das autoridades brasileiras em relação à maconha na década de 1930, muito distante da indiferença que dominou a questão por quase duas décadas desde o alarme médico em 1915.

Municiado dessas instruções e a par dos principais interesses do governo brasileiro, partiu Jorge Latour para Genebra em junho de 1936 na condição de delegado plenipotenciário do país na Conferência. Em seu relatório, o representante brasileiro apresenta, de início, uma "recapitulação histórica" dos trabalhos da Liga para a realização da Conferência; na sequência faz um "resumo do ocorrido" e então discute longamente os debates das assembleias; informa como foram cumpridas por ele as instruções elaboradas pela CNFE; e também tece considerações que não deixam dúvidas sobre a importância assumida pela questão do consumo de drogas naquele momento. (BRASIL, 1936e, p. 5)

Estiveram presentes na conferência 42 países diferentemente aparelhados e influentes. Alguns "já gozavam da intimidade de Genebra", a exemplo dos Estados Unidos, outros possuiam "[...] detalhadas instruções sobre as questões que se iam debater". (BRASIL, 1936e, p. 5) Havia ainda os países cujos representantes eram membros da liga, como a Grã-Bretanha, a Áustria, a Holanda, a França e o Uruguai. Alguns inclusive se 
Sonhos da diamba

faziam representar por "delegação composta de seis membros", como era o caso do Japão. Jorge Latour, por outro lado, era o único representante brasileiro em Genebra, foi nomeado a uma semana do início da Conferência e tomou conhecimento apenas dois dias antes. (BRASIL, 1936e, p. 4) Isso o levou a admitir que não teve "destacada posição nas discussões", já que para tanto seria necessário que o projeto de Convenção "houvesse sido, de antemão, estudado pelo Itamaraty", permitindo-o atuar "mais solida e autorizadamente". (BRASIL, 1936e, p. 7)

Importante destacar que o delegado brasileiro deixou entrever em seu relatório que a Conferência de Genebra, longe de ser um fórum harmônico e homogêneo que reunia países preocupados com os efeitos nocivos dos entorpecentes para a humanidade, era uma verdadeira batalha campal entre potências econômicas rivais: "A Conferência achava-se dividida por interesses [...]. Por isso mesmo, logo ao ser discutido o artigo primeiro da Convenção, tinha começo o conflito de pontos de vista diametralmente opostos". (BRASIL, 1936e, p. 8)

Grupos e bancadas se formavam em torno de determinados interesses comuns, como o que ele chamou de "Bloco do Ópio", reunindo países que faziam parte da cadeia produtiva das drogas farmacêuticas como Reino Unido, Índia, França, Portugal e Holanda. Nas sessões em que foi discutido o dispositivo que previa punições severas para "a cultura, a colheita e produção de plantas psicoativas", uma das letras do Artigo I, esses países "instantaneamente arregimentaram-se na tribuna" e "[...] juntamente queriam a queda do dispositivo, [...] verificando-se uma grave crise". (BRASIL, 1936e, p. 12) Da maneira como estava colocado, o dispositivo afetaria a todas as formas de cultura das plantas psicoativas, prejudicando, particularmente, os interesses industriais europeus. 
Os Estados Unidos propuseram uma emenda ao texto do Artigo I que causou grande hostilidade dos países do bloco, chegando sua delegação a ficar "pronta a abandonar os trabalhos" devido às reações contrárias. (BRASIL, 1936e, p. 9) Os debates acerca do Artigo I da Convenção se arrastaram por nove dias e treze sessões, nas quais com frequência Latour emprega termos como "intransigência", "crise", "grande tensão" e "atmosfera pesada". Apesar da criação de um Comitê de conciliação, os países do bloco não assinaram o texto final do dispositivo e os Estados Unidos não subscreveu o texto definitivo da Convenção.

Em linhas gerais, o posicionamento do Brasil foi alinhado ao dos Estados Unidos, delegação com a qual Latour manteve, segundo suas palavras, "cordiais relações e certa intimidade". (BRASIL, 1936e, p. 9) Nas discussões do Artigo I, o ponto mais importante da Conferência, suscitando "debates acalorados" e rupturas, a proposta norte-americana só foi apoiada por Brasil e China..$^{5}$ Latour considerava o "serviço policial repressivo" dos Estados Unidos em matéria de entorpecentes "o melhor modelo para a nossa polícia repressiva". (BRASIL, 1936e, p. 38) O delegado comungava do princípio básico do modelo proibicionista norte-americano, o de que toda a produção de drogas deveria ser regulada estritamente "em face das necessidades médicas e científicas do mundo". Era um dos países com os quais o Brasil tinha "afinidades de pontos de vista" no assunto, com o qual um "concerto prévio de atitudes" poderia "quebrar a resistência do Bloco do Ópio", condição necessária para que se alcançasse uma "franca politica supressiva" em escala global. (BRASIL, 1936e, p. 43)

5 Vale salientar que a China havia sido auxiliada pelos Estados Unidos na Conferência de Xangai em 1909 quando buscava eliminar a importação do ópio anglo-indiano, comércio monopolizado pela Inglaterra desde o fim da I Guerra do Ópio em 1845. (RODRIGUES, 2008; SCHEERER, 1993) 
Sonhos da diamba

A visivel opinião favorável ao modelo norte-americano expressada pelo delegado do Brasil na Conferência de Genebra em 1936 tinha um fundamento na relação que os dois países teceram ao longo da década de 1930. Se um intercâmbio maior em matéria de entorpecentes se dá ainda no governo do presidente Hoover, foi durante os sucessivos mandatos do seu sucessor, Franklin Roosevelt, a partir de 1933, que ele se intensificou. Os anos 1930 foram mais significativos que qualquer outro periodo nesse quesito até então. Relatórios e leis foram compartilhados e correspondências trocadas, fortalecendo o poder da grande potência sobre os rumos da política nacional de repressão às drogas.

Já em 1931 a Agência Federal de Narcóticos, em inglês, Federal Bureau of Narcotics (FBN), enviava ao governo brasileiro uma "Disposição sobre entorpecentes apreendidos sob Leis Federais de Narcóticos". (BRASIL, 1931) Tratava-se de "instruções para fiscais de alfândega" nos Estados Unidos: como procederem em casos de importação e exportação de entorpecentes, sobretudo nas situações de apreensão. Não foi encontrado nenhum documento que nos indicasse ter o governo brasileiro solicitado a "Disposição", contudo é possivel que se tratasse de prática tornada comum pela recém-criada agência. A criação do órgão central em 1930 permitiu a expansão do modelo oficial norte-americano de gestão do fenômeno para além das suas fronteiras, como um componente cada vez mais indissociável da sua política externa. (BECKER, 2009a)

Como foi dito, com a chegada de Franklin Roosevelt ao poder em 1933 essa relação vai se estreitando. É nesse contexto que o Ministério das Relações Exteriores, em memorando de 11 de abril de 1936, recebe "informações sobre a "maconha" fornecidas pelo diplomata norte-americano A. Duke, que diz: 
É planta que fornece o 'hachich' do oriente, entorpecente perigoso que produz às vezes loucura criminosa. Introduzida no Brasil pelo tráfico de escravos, espalhada, sobretudo ao longo da costa norte, por exemplo, no 'Salgado' paraense, no Maranhão, na Bahia. (BRASIL, 1936f, p. 1)

Coincidentemente, a opinião do diplomata sobre a maconha no Brasil em muito converge com as considerações feitas por Rodrigues Dória em 1915: provocava loucura e levava à prática de crimes, sua origem era africana e a principal região de consumo era o "norte", incluindo aí a Bahia. Quanto à "loucura criminosa", também era tese já amplamente aceita pelas autoridades dos Estados Unidos e quanto às outras duas pontuações, não é tão improvável que o diplomata norte-americano pudesse ter tido contato com "Os fumadores de maconha”, já que era a principal referência nacional no assunto e lá foi apresentado em congresso na capital, Washington.

Em 1936 a maconha ainda não era alvo de regulação federal nos Estados Unidos, o que veio a ocorrer no ano seguinte com a aprovação do Marihuana Tax Act. Diferentemente dos opiáceos e do álcool, objetos de intervenção do Estado norte-americano por meio do Harrison Act de 1914 e do Volstead Act, a conhecida Lei Seca, de 1919, a maconha teve até a primeira metade da década de 1930 uma frouxa aplicação de leis restritivas estaduais. Seu consumo começa a ser notado entre imigrantes mexicanos na década de 1920, mas, de início, não despertou muita atenção das autoridades, dos médicos, da imprensa nem dos muitos grupos de "moralização do país" surgidos em torno dos valores puritanos desde fins do século XIX e que tinham na "Anti-Saloon League" e no "Prohibition Party" seus modelos mais acabados e poderosos. (BECKER, 2009b; RODRIGUES, 2008)

Ao longo dos anos trinta se intensificou a campanha do FBN no sentido da criação de normas a nível nacional para 
unificar a repressão às drogas. Todo o aparato repressivo montado para o controle do consumo de álcool, que incluía o FBN, milhares de agentes e grandes verbas estatais, passava a se voltar para a maconha depois que a Lei Seca foi revogada em 1933. ${ }^{6}$ Com a manutenção de um intenso fluxo migratório de mexicanos para o país, em pouco tempo a condenação da maconha tomaria os meios de comunicação e as páginas dos artigos científicos nos Estados Unidos. Estes transmitiam dados fornecidos pelo FBN sobre uma grande variedade de crimes que teriam sido cometidos por usuários de maconha e, principalmente, associavam bastante os imigrantes latinos à droga. (ESCOHOTADO, 2004; RODRIGUES, 2008) A agência alcançou seu objetivo em 1937 quando o Congresso Nacional aprova a Lei de Tributação da Maconha, rapidamente evoluindo para tornar ilegal todo uso não medicinal ou não científico da planta no país. ${ }^{7}$

Em 28 de setembro daquele mesmo ano de 1937 o embaixador dos Estados Unidos no Brasil, encaminhava uma cópia do Marihuana Taxt Act ao Itamaraty e solicitava ao Ministro das Relações Exteriores “[...] cópias das leis e regulamentos do Brasil, tanto a nivel federal quanto estadual, concernentes à importação de Cannabis sativa (marihuana) e seus derivados". (BRASIL, 1937, p. 1) Seis meses depois, em março de 1938, o ministro brasileiro responde ao embaixador norte-americano,

6 Com as profundas dificuldades econômicas derivadas da crise de 1929, o Estado e as elites econômicas passaram a advogar o fim da proibição com o objetivo de aumentar a receita estatal a partir da arrecadação de tributos sobre o comércio de bebidas alcoólicas, capital acumulado por mais de uma década no complexo mercado ilegal surgido com a criminalização.

7 Para aprová-la foram feitos arranjos político-econômicos com produtores de óleo de sementes de cânhamo e de alimentos para animais, adequando a linguagem do projeto às suas especificidades para que não prejudicassem suas indústrias. (BECKER, 2009) 
encaminhando uma declaração prestada por órgão do Ministério da Agricultura que assim concluía:

O Serviço de Defesa Sanitária Vegetal não possui regulamentos sobre marihuana, diamba, cânhamo verdadeiro - Cannabis sativa - de que necessita o Sr. Embaixador dos Estados Unidos da América do Norte, por isso que a legislação que lhe incumbe conhecer e cumprir é a sobre parasitas nocivos às plantas. (BRASIL, 1938b)

É curioso o fato de que não se tenha mencionado o Art. $2^{\circ}$ do Decreto n. ${ }^{\circ} 20.930$ de 1932 que regulava, entre outras coisas, a importação das "substâncias tóxicas entorpecentes" listadas no Art. $1^{\circ}$, onde figurava pela primeira vez a maconha. (BRASIL, 1932) Talvez por estar aí designada como Cannabis indica ou por que realmente não havia uma norma específica que regulasse a matéria da importação da maconha. Ao que tudo indica, o funcionário do Ministério da Agricultura desconhecia a legislação e expressou a sua opinião de técnico em assuntos agrícolas. De qualquer modo, o que importa é deixar claro como esse interesse dos Estados Unidos estava em sintonia com o estreitamento de relações que o país vivia com o Brasil na questão do controle de drogas, principalmente da maconha, e que esse processo ganhava novo impulso com a aprovação da Lei de Tributação em 1937.

Logo no início de 1939 novas informações chegariam da América do Norte. Em 27 de janeiro, atendendo a um pedido do ministro das Relações Exteriores do Brasil, o Departamento de Estado enviou ao Itamaraty “[...] cópias de todas as leis e regulamentos em efeito nos Estados Unidos da América concernentes ao controle do tráfico de drogas narcóticas". (BRASIL, $1939 b$, p. 1) E nos dias 17 de fevereiro e 27 de março daquele ano, o ministro receberia ofícios do embaixador informando 
que cidadãos brasileiros haviam sido detidos devido ao uso ilícito de maconha nos Estados Unidos.

No primeiro caso Augustine (Augusto) Rios e João (Dolores) Rodrigues foram presos no píer n. 8 do porto de Locus Point, em Baltimore, com dois quilos de maconha por um fiscal da alfândega. Ambos eram tripulantes do navio Parnahyba, a serviço do Lloyd Brasileiro. O navio partiu do porto de Santos no dia 20 de setembro de 1938 com destino a Baltimore, mas antes havia passado no Rio de Janeiro, na Bahia e em Nova Iorque. A prisão foi tensa e um dos dois acabou ferido no braço esquerdo por um disparo do fiscal, porém não se sabe qual, pois o relatório é bastante sucinto na descrição do ocorrido e não informa o nome do baleado. (BRASIL, 1939c)

A segunda ocorrência transmitida pelo governo norte-americano relatou a prisão de Raimundo dos Santos pouco mais de um mês depois no Brooklyn, em Nova Iorque, com aproximadamente cinquenta gramas de maconha nos bolsos. Raimundo foi o único a ter uma característica racial mencionada no "Relatório de Apreensão de Narcóticos" enviado em anexo: "brazilian negro". Era tripulante do navio Balzac, propriedade da Lamport and Holt Line da Inglaterra, que partiu de Santos com destino a Nova Iorque em 29 de dezembro de 1938. Antes aportou no Rio de Janeiro, no Maranhão e no Pará. Mas Raimundo afirmou que adquiriu a erva em Pernambuco, numa feira livre. E parece ter dito mais: segundo o relatório, Raimundo se defendeu explicando que faria uso medicinal da maconha "com água quente e açúcar na forma de chá", uma infusão boa "como tratamento para resfriados, dores de cabeça e constipação". (BRASIL, 1939d)

O caráter sintético dos relatórios não nos permite concluir muitas coisas, sobretudo no primeiro caso. O guarda apenas relata que desconfiou da presença dos dois homens no píer 
e decidiu abordá-los. É possivel supor que a associação da maconha com os imigrantes latinos, notadamente mexicanos, nos Estados Unidos tenha informado de alguma maneira a desconfiança do oficial. Este, por sinal, era um fiscal do porto e sabia que o navio Parnahyba vinha da América Latina. No segundo caso, a associação étnica é clara, o oficial responsável pela prisão destacou que Raimundo era um "negro brasileiro", se aproximando coincidentemente de uma visão partilhada por aqui que ligava os negros à maconha. Outro detalhe que chama a atenção é o emprego medicinal da erva alegado por Raimundo: ainda que possa ter sido um artifício retórico para minimizar as consequências da prisão, ${ }^{8}$ não deixava de ter suporte na sociedade brasileira à época, como se verá mais adiante.

De fato, o Estado no Brasil se voltou contra o uso da maconha antes dos Estados Unidos. Aqui em 1932 e lá em 1937. Aqui primeiro veio uma norma federal, enquanto lá essa foi a última etapa do processo. O nosso Decreto n. ${ }^{\circ} 20.930 / 32$ proibiu toda forma de uso que não fosse permitida pelas autoridades sanitárias, já o Marihuana Taxt Act primeiro tributou exorbitantemente a produção não medicinal ou científica, buscando coibir o seu uso psicoativo com a elevação dos preços e só depois se transformou em proibição expressa.

A década findava e a presença dos Estados Unidos na questão crescia e se diversificava. Entre disposições e leis sobre o controle e repressão estatais aos entorpecentes em geral, o intercâmbio focalizou a maconha, especificamente, no período em que crescia por lá uma percepção condenatória do seu uso psicoativo. Apesar das diferenças, ambas as experiências estão conectadas, o que ajuda a compreender, em certa medida, os

8 O problema do uso da maconha nos Estados Unidos era, sobretudo, o seu emprego na busca do que as autoridades consideravam "prazeres ilícitos", sendo reconhecida a legitimidade do uso medicinal cientifico. (BECKER, 2009b) 
caminhos escolhidos pelo Estado brasileiro na questão, prevalecendo o modelo proibicionista. Essa perspectiva passava a ganhar cada vez mais adeptos entre as nações americanas ao longo da década de 1930. Tomem-se brevemente alguns exemplos no período.

Em agosto de 1934 o Congresso da Venezuela aprovava a sua "Ley de Estupefactivos", tornando “[...] absolutamente proibidos a importação, o comércio, toda forma de distribuição e uso [...] do ópio, do cânhamo da Índia preparado para fumar", da resina obtida da planta, "[...] das variedades botânicas similares e das preparações que contenham a dita resina", entre outras substâncias. (BRASIL, 1934b, p. 2) Como se pode ver, a lei dedicou grande atenção à maconha, designada como "cânhamo da Índia", termo empregado usualmente pela Liga das Nações para se referir à planta. ${ }^{9}$ Não por acaso, fazia menção expressa à Convenção de Genebra de 1931, destacando a necessidade do país se adequar às suas definições. (BRASIL, 1934b)

No ano seguinte foi a vez do Chile aprovar o seu "Regulamento de Estupefacientes", fruto de um projeto apresentado no mesmo ano pelo Conselho Geral de Saúde Pública. A maconha também figurou na lista proibitiva, sendo permitida apenas a produção "[...] destinada a satisfazer as necessidades médicas e científicas do país". (BRASIL, 1935a, p. 2) Ainda em 1935 o governo do Chile firmou com a Argentina um convênio "[...] para cooperar na ação da Liga das Nações para a repressão do tráfico de ópio e outras drogas nocivas", visto que as autoridades dos dois países denunciavam a existência de um tráfico dessas substâncias entre suas fronteiras. (BRASIL, 1936g, p. 1)

9 Esse formulário continha instruções do organismo para os governos dos países preencherem corretamente o Relatório Anual devido à Liga e nele a maconha é tratada como "chanvre indien", expressão francesa que significa cânhamo indiano. (BRASIL, 1934b, p. 5) 
Em 1938 a Argentina também consolidava o modelo proibicionista com um "Decreto de Reglamentación del Tráfico de Estupefacientes". O decreto foi publicado no jornal La Nación de 24 de fevereiro de 1938 e pontuava ser necessário "[...] incorporar ao país, de forma intensa, esse movimento de coordenação e cooperação internacional" capaz de "[...] opor uma barreira eficaz ao desenvolvimento de uma praga que toca em parte vital do organismo nacional". (BRASIL, 1938a, p. 3) A maconha também não deixou de ser elencada entre os estupefacientes de uso proibido, aqui também referida como "cânhamo indiano".

Apesar de não representar a totalidade do processo que levou a um ostensivo controle e repressão das drogas na América Latina, os exemplos acima são significativos das linhas gerais que orientavam o movimento na época. Sem perder de vista as diferenças entre os diversos países do continente, havia pontos de convergência que uniam as várias experiências proibicionistas nacionais ou pelo menos as colocava numa mesma direção.

Em todos os casos foi evidente e expressa a influência do contexto internacional na aprovação das normas. Os países buscavam atender às diretrizes estabelecidas pela Liga das Nações: atualizavam normas e mecanismos internos na matéria em função das disposições desse organismo. É significativo nesse sentido o termo utilizado em todos os casos para se referir à maconha, "cânhamo indiano" ou "cânhamo da Índia", como dito, os mesmos usados pela Liga. Percebe-se também como a maconha não era considerada um problema apenas no Brasil, pois todos os países mencionados acima a inseriram em suas listas proibitivas. Outro ponto em comum nesses casos foi a criminalização dos usos tradicionais da folha de coca, comum a diversas culturas presentes nesses países. Enfim, todo o uso não medicinal ou científico das drogas, fossem "sintéticas" ou "naturais", passou a ser visto de maneira generalizada como 
uma "praga" que merecia o esforço individual de cada governo, assim como a cooperação com governos vizinhos e com o organismo central internacional para o seu combate.

Foi esse o contexto internacional em que se inseriu o proibicionismo brasileiro no momento de seu nascimento e estruturação na década de 1930. Por um lado, havia a presença forte da Liga das Nações, organismo que, mesmo não tendo a unidade que aparentava, estabelecia regras e mecanismos de controle cada vez mais amplos e angariava mais e mais aliados à causa do proibicionismo global. Por outro, os Estados Unidos definiu o proibicionismo das drogas como uma das bases da sua política externa, exercendo grande influência em todo o continente americano e especialmente na manutenção do modelo proibicionista oficial que se estabeleceu no Brasil.

Contudo, seria equivocado sustentar que a experiência brasileira se tratou de mera reprodução de um processo externo. A repressão às drogas no Brasil foi, acima de tudo, um esforço consciente que adequou propostas e mecanismos às demandas de controle social internas. Por isso foi possivel reprimir o uso psicoativo da maconha em meados do século XX, com base em ideias em circulação no mundo e numa ideologia racista e excludente de décadas anteriores, criminalizando a pobreza, abrindo mais uma porta de acesso às classes subalternas e justificando a intervenção violenta do Estado sobre elas.

Assim, cabe questionar: por que o proibicionismo das drogas no Brasil se desenvolve sistematicamente nas décadas de 1930 e 1940, mais especificamente sob a batuta do primeiro governo Vargas? Quais as características da realidade histórica que podem nos ajudar a compreender por que a questão dos entorpecentes assume uma especificidade nesse período? E por que o discurso condenatório da maconha encontra a receptividade, que levaria à criminalização, por parte do Estado ape- 
nas no pós-1930? Para refletir sobre estas questões, é preciso revelar os pontos de conexão entre as mudanças vivenciadas pela sociedade brasileira naquele contexto e a nova postura do Estado diante dos usos das substâncias psicoativas. É fundamental, então, situar esse recorte no cenário da época, momento de intensas disputas de poder e lutas sociais, bem como da emergência de novos atores na arena politica.

O regime político instaurado no país após o movimento de 1930, chamado também "Revolução de 30", que teve na figura de Getúlio Vargas sua maior liderança, foi fundamentado num pensamento autoritário, marcadamente influenciado pela experiência do totalitarismo europeu, ainda que buscasse dele se distinguir. Mesclou uma nova política de massas, objetivando o controle social, com a preocupação em evitar a expansão mundial do comunismo. Teve destacada participação da intelectualidade e da tecnocracia nacional para por em prática um modelo de governo estatista, doutrinário e racionalizado. Apropriou-se dos meios de comunicação e dos canais de expressão da sociedade para promover uma intensa campanha de desmobilização social e formação de outro tipo de sujeito, mais adequado à ideologia do regime: o cidadão saudável, trabalhador e patriota.

Porém, sua enorme complexidade não nos permite apenas este olhar. A relação do líder carismático com as classes trabalhadoras, só para citar uma das faces mais emblemáticas do regime, era extremamente ambígua: se a legislação social agradava a muitos, incorporando direitos à vida dos operários, para outros tantos representava a perda da autonomia e a sua subordinação; se o chefe exigia, como retribuição das suas "benesses", a obediência e a colaboração da coletividade, essa não se dava de forma tácita, cega e inconsciente, revelando um intricado jogo de interesses. O período também não foi um todo 
Sonhos da diamba

homogêneo nem linear, mas um processo com momentos de indefinição e múltiplos projetos, mudanças de regime e reconfiguração de regras.

Uma das intenções do regime era mudar a estrutura econômica do Brasil. Essa política econômica teria como metas a substituição das importações e o desenvolvimento de novas atividades econômicas, com ênfase no setor industrial. (BASTOS, 2006) Para isso era preciso agir também sobre as relações de trabalho. O primeiro governo Vargas como um todo e, mais intensamente, o Estado Novo se esforçaram por racionalizar o mundo do trabalho. Isso significava, por um lado, mediar os conflitos entre patrões e trabalhadores e, por outro, controlar os sindicatos. A política trabalhista, que culminou na promulgação da Consolidação das Leis do Trabalho (CLT) em 1943, revelou o quanto essa dimensão era importante para o projeto governamental do regime. Estas ações eram inspiradas pelas reivindicações dos movimentos sociais anteriores a 1930 e resgatavam a autoimagem e as tradições de classe construída pelos trabalhadores durante as lutas do período. (CAPELATO, 2003)

Ao atender a essas demandas, habilmente, o regime operava uma releitura desses elementos, transformando-as em dádivas do governo, em "benesses" concedidas pela "generosidade" de Vargas, daí seu título de "pai dos pobres". Tal operação acionava, em novas vias, mecanismos do paternalismo há muito arraigados na sociedade brasileira. Mas também fazia eco ao contexto internacional, no qual emergiam no cenário político grandes líderes carismáticos e projetos políticos de massas na Europa e na América, processo comumente conhecido como "populismo". A contrapartida da sociedade seria o reconhecimento do chefe político e a retribuição por meio do trabalho e da colaboração com o regime. (FERREIRA, 2001; NEGRO, 2004) 
É inegável o impacto de um projeto governamental organizado em torno da exaltação do trabalho e do trabalhador, que o colocava dentro da cena política, convocava a colaborar na construção de uma nação e conferia-lhe um papel, até então negado pelo Estado, de cidadão ativo. Isso se encaixava de forma singular nos anseios da classe trabalhadora. A legislação trabalhista, regulamentando as relações de trabalho, sem dúvidas, trouxe beneficios que foram transformados em direitos adquiridos e extrapolaram as limitações legais, o meio urbano e o ambiente das fábricas. Também é inegável o autoritarismo, a repressão e a intenção de subordinar os trabalhadores subjacentes ao processo que, se os convocava para a participação politica, lhes impunha restrições, ou seja, essa deveria se desenvolver dentro dos limites estabelecidos pelo regime. (DEZEMONE, 2007; GOMES, 2005)

Essa intensa presença nos diversos níveis da vida social refletia o pensamento autoritário sobre o qual se assentou o regime político pós-1930, sobretudo, o Estado Novo. O pensamento autoritário brasileiro foi expresso em nomes como Oliveira Vianna, Azevedo Amaral e Francisco Campos. Partia do pressuposto de que o coletivo, foco primordial das ações do Estado, é imaturo, fragmentado e despreparado para a vida política livre, necessitando de um guia, que seria o Estado forte e centralizador, o único capaz de assumir essa tarefa em proveito do "bem comum". Segundo seus ideólogos, o liberalismo seria uma "ideologia importada", alheia à "indole nacional" enquanto o Estado Novo seria a "autêntica expressão" da nacionalidade. (ROLIM, 2010; SOUZA, 2004a; VELLOSO, 2003)

A construção e divulgação da ideologia do regime foram encabeçadas pelo Ministério da Educação e pelo Departamento de Imprensa e Propaganda (DIP). O primeiro esteve entre as primeiras medidas de Vargas na presidência, ficando a maior 
parte do período sob as ordens de Gustavo Capanema, e o segundo foi criado em 1939 e entregue a Lourisval Fontes. Tinham sob sua responsabilidade planejar e divulgar a doutrina oficial através de diversos canais de expressão. A propaganda foi um dos instrumentos mais característicos desse processo, mas é apenas uma das dimensões da ampla política cultural do Estado Novo.

Naquele contexto, a cultura tornou-se um terreno privilegiado de ação do Estado, estando a sua política norteada por uma dupla preocupação: construir a sua legitimação na sociedade e ampliar a sua base de apoio. Para isso levou a cabo um extenso controle dos meios de comunicação e uma larga ocupação dos "canais de expressão da sociedade civil", intervindo em diversas áreas da produção cultural, desde o rádio ao teatro, passando pela música e pelo cinema. Censurava comportamentos e valores que não convergissem com a sua perspectiva e se apropriava de mitos, lendas, símbolos, narrativas, imagens e tradições presentes na sociedade sobretudo entre as classes trabalhadoras.

Atuação baseada numa ambígua percepção do povo brasileiro: naturalmente "bom" e "criativo", mas precisava ser "civilizado", "educado" para fazer parte da comunidade abrigada pela cidadania. Em outras palavras, a cultura deveria ser transformada em instrumento pedagógico do governo. Por isso o Estado Novo buscou "civilizar o samba", censurando o tema da malandragem e estimulando, inclusive com premiações, a exaltação do trabalho e das ações do governo. Além disso, houve a produção de documentários, peças teatrais, músicas e publicações diversas que tinham como tema central o governo e Vargas. Assim como na questão da legislação social e trabalhista, este processo foi complexo, não se podendo admitir como verdade absoluta que a mensagem do regime era entendida pe- 
los seus destinatários da forma como ele impunha. (GOMES, 1998; VELLOSO, 2003)

O foco dessa política foi o conjunto da sociedade, o coletivo. O Estado autoritário focaliza o coletivo na sua ação ideológica, pois é nele que busca a sua legitimidade social. Para Nelson Hungria, um importante criminalista do período, a nova realidade sociopolítica do país demonstrava a "necessidade de um ajustamento entre o todo social e o indivíduo, entre o Estado e a célula individual". Nota-se que nessa inflexão o Estado é o mesmo que o "todo social", ideia básica do pensamento autoritário. O Estado, devido à sua inabdicável soberania intervinha para garantir o equilíbrio e a harmonia social. Deveria canalizar a capacidade realizadora do indivíduo e utilizá-la no interesse do bem geral, que seria o do próprio indivíduo. (HUNGRIA, 1941 apud ROLIM, 2010, p. 75)

Foi com essa justificativa que a ordem jurídica foi reformulada, buscando adequá-la à nova realidade e suas regras, sendo exemplar desse processo o Código Penal de 1940. Se surgiam novos atores sociais, deveriam ser criados o maior número de figuras e situações penais possiveis. Nas palavras de seus idealizadores, as mudanças sociais do pós-1930 implicavam na mudança do direito penal liberal, esteio do Código de 1890, que seria individualista e ultrapassado: "ponto de mira [...] deixou de ser o indivíduo e passou a ser a coletividade". (HUNGRIA, 1941 apud ROLIM, 2010, p. 75)

Entretanto, essa reformulação da ordem jurídico-penal demonstrou uma visão eugênica da criminalidade. Isso quer dizer que se pensava que os delinquentes são incapazes de viver livres e precisam de tutela, sendo essa ação desviante algo inato a esses individuos. Eram os pobres, considerados inferiores devido a fatores étnicos e "anormais" com "taras hereditárias" de famílias deficientes. Nas palavras de Nelson Hungria eram 
uma "subespécie de homo sapiens". (HUNGRIA, 1941 apud ROLIM, 2010, p. 75) Para tratar eficientemente esse problema não bastariam as punições, deveria o Estado atuar disciplinando e educando esses grupos para que pudessem ser incluídos na sociedade. Corrigir para incorporar.

A ciência teve lugar de destaque no contexto, sendo desenvolvido "[...] um conjunto de princípios de investigação científica do delito e da eficácia das penas" auxiliado e reforçado pelo largo emprego das estatísticas. (ROLIM, 2010, p. 83) A partir da década de 1930 haveria a formação de conselhos técnicos no governo, uma novidade do regime, que buscava uma racionalidade administrativa. Outro dado significativo foi a penetração das ciências médicas no interior do Estado, saindo das ligas eugênicas para ocupar diversos postos na administração pública. Prossegue-se, não sem dificuldades, o processo de tentativa de "medicalização da sociedade" e mais do que nunca o da "medicalização das políticas públicas" de controle. (CAPELATO, 2003; CUNHA, 1986)

Tal tentativa de medicalização caminhava lado a lado com a busca da moralização, centrada na figura do "bom trabalhador" e difundida nas intervenções do regime junto aos canais de expressão da sociedade. O "cidadão brasileiro" desejado precisava ser cívico e sadio. Essas duas dimensões apresentaram uma forte ligação durante o período, sobretudo no Estado Novo. A atenção e o estímulo à atividade física podem ser tomados como exemplo. Obrigatória desde 1931 em todas as classes secundárias, a educação física era vista como meio para o desenvolvimento de virtudes cívicas, o fortalecimento de sentimentos patrióticos e, principalmente, para o "aprimoramento racial". O calendário cívico construído pelo regime conferia um espaço significativo para demonstrações de atividades físicas incorporadas aos desfiles públicos, por exemplo. 
(PARADA, 2004) Esse processo revelou a preocupação com a produção de um corpo sadio e disciplinado capaz de simbolizar a ordem e a dedicação à comunidade nacional.

Através de cartazes, exibições em cinemas, publicações impressas, peças de teatro, programas de rádio, cartilhas escolares e outros veículos pretendia-se fazer do corpo saudável e disciplinado do cidadão uma representação do "corpo da nação". As classes trabalhadoras, como foco privilegiado da atenção do regime, deveriam ser depuradas dos comportamentos indesejados, por isso "combater os vícios", fossem o álcool ou os "entorpecentes", estes seriam os responsáveis pela "degeneração racial" e por doenças fisiológicas, mentais e sociais. Dessa forma, pode-se supor que determinadas substâncias psicoativas passam então a ser criminalizadas, não apenas por que assim se processava no exterior, mas também por que representavam uma ameaça a esse modelo de "homem novo" idealizado: trabalhador, cívico e saudável. Não por acaso a "embriaguez habitual pelo álcool ou substância de efeitos análogos” será, com o Código Penal de 1940, conduta passível de internação compulsória.

Como visto, a criminalização ostensiva de determinadas substâncias psicoativas no Brasil, após um periodo de medidas pontuais, encontrou sua efetivação ao longo das décadas de 1930 e 1940. Período fértil em projetos de controle de massas em que, na maior parte do tempo, esteve no poder central Getúlio Vargas e uma elite política que planejava operar uma profunda mudança no país sem alterar a hierarquia social. Focando agora no coletivo, o regime se esforçou por "moralizar" a sociedade, estabelecendo padrões de conduta aceitos, ao mesmo tempo em que reformulava a ordem jurídica, criando novos ou ampliando os tipos de crimes e criminosos, os desviantes dos comportamentos legitimados. Longe de ser apenas 
uma reprodução do que acontecia no plano internacional, esse processo possuía um filtro próprio, que adequava normas, saberes e mecanismos às especificidades e demandas repressivas internas.

Um exemplo desse filtro próprio é o Decreto n. 20.930 de 11 de janeiro de 1932. Foi a primeira norma jurídica a tratar da questão da produção, comércio e consumo de drogas no governo Vargas. Com ela o Estado passaria a controlar doze substâncias, quatro vezes mais do que previa a lei em vigor sobre a matéria, de 1921. Tornaram-se "substâncias tóxicas de natureza analgésica ou entorpecente" o ópio bruto e medicinal, a morfina, a diacetilmorfina ou heroína, a benzoilmorfina, a dilandide, a dicodide, a eucodal, as folhas de coca, a cocaína bruta, a cocaina refinada, a ecgonina e a Cannabis indica. (BRASIL, 1932c, p. 1)

Segundo o preâmbulo do decreto, a medida se dava "[...] de acordo com a solicitação do Comitê Central Permanente do Ópio da Liga das Nações". (BRASIL, 1932c, p. 1) A Liga havia produzido uma convenção internacional no ano anterior, 1931, para "limitar a fabricação e regulamentar a distribuição dos estupefacientes", promulgada no Brasil pelo Decreto n. ${ }^{\circ} 113$ de 1934. (BRASIL, 1935h, p. 306) No geral, a convenção buscou normatizar a questão, sobretudo na sua dimensão econômico-comercial, de forma a conciliar os interesses de diversos países do setor farmacêutico. Porém, também estabeleceu dispositivos que extrapolavam o campo do econômico. O Brasil foi signatário da convenção sendo representado na conferência pelo diplomata Raul do Rio Branco.

Nada de excepcional então, pois subscrevendo a convenção o governo se responsabilizava a operacionalizar no território brasileiro as suas disposições. Mas um detalhe nos permite perceber a especificidade do proibicionismo que se formava no 
Brasil: no artigo I da convenção, que define as "drogas" a serem controladas mundialmente, divididas em "Grupo I" e "Grupo II", não está a maconha. As únicas substâncias psicoativas em estado natural inseridas foram o ópio e a folha de coca, mas nada se disse sobre a "Cannabis sativa", ou sua variedade "indica". Nem mesmo existe no texto o termo "cânhamo indiano", usado pela Liga para tratar da maconha.

Entretanto, como visto, o Decreto n. 20.930 de 1932 a inseriu, sob o nome de Cannabis indica, em sua lista proibitiva, menos de um ano após o governo ter assinado a Convenção de Genebra. Explicar os motivos que levaram a ausência da maconha nas listas de drogas de uso proibido pela Liga das Nações entre 1931 e 1961 é algo que somente será possivel através de estudos específicos sobre as relações internacionais hegemônicas no período dentro do organismo, mas é possivel continuar tentando entender os motivos que levaram à sua proibição no Brasil. ${ }^{10}$

Em 1936 foi dado um passo fundamental para a consolidação desse processo, a montagem da CNFE. A criação de um comitê nacional para organizar e liderar o combate às drogas no Brasil foi uma ideia manifestada pela primeira vez em 1916. (BRASIL, 1916a) Porém, não passou da manifestação de uma ideia, não houve ações por parte do governo brasileiro no sentido de materializar tal comitê, o que só aconteceria vinte anos depois. As iniciativas nesse sentido se iniciaram em 1935 quando determinadas autoridades do governo federal começaram a alegar a necessidade de "[...] sistematização do serviço repressivo [...] contra a propagação da toxicomania e contra o

10 É importante frisar que a maconha não aparece nas listas de substâncias proibidas pelas convenções, mas está, paradoxalmente, presente em outras publicações da liga, a exemplo dos "Formulários" com instruções do organismo para o preenchimento, por parte dos governos, dos "Relatórios Anuais sobre tráfico de drogas nocivas". 
tráfico ilícito de estupefacientes”. (BRASIL, 1935a, p. 2) Pode-se evidenciar o embrião desse esforço através de um ofício enviado por José Carlos de Macedo Soares, Ministro das Relações Exteriores, a Gustavo Capanema, Ministro da Educação e Saúde, no início de 1935:

Com efeito, seria aconselhável provocar um entendimento estreito [...] mediante o contato direto e coletivo entre as autoridades e funcionários que, nas diferentes repartições participam de qualquer modo do serviço de repressão internacional e nacional do tráfico ilícito e abuso dos estupefacientes. (BRASIL, 1935a, p. 2)

Macedo Soares enfatizava a urgência desse contato direto, pois "[...] a administração federal nem sempre fica, em tempo, aparelhada para executar convenientemente as Convenções a que o Brasil se vincula, tornando 'letra morta' diversos dispositivos desses acordos". Sendo assim, era necessário "provocar um entendimento estreito" entre as "várias repartições" para concretizar de maneira eficiente o "serviço de repressão". (BRASIL, 1935a, p. 1-2)

Com a concordância de Capanema, o Itamaraty, envia, no dia 5 de julho do mesmo ano, convites para os Ministérios da Fazenda, da Justiça e do Trabalho, assim como para a "Chefatura de Polícia do Distrito Federal" e para a "Inspetoria da Alfândega do Rio de Janeiro", solicitando que mandassem "representantes às reuniões de estudos", no intuito de criar um "[...] órgão realmente eficiente no combate ao flagelo social das toxicomanias". (BRASIL, 1935c, p. 1-2) O órgão, inicialmente, deveria se chamar "Comitê Nacional Permanente do Ópio e outros Estupefacientes" e entre suas atribuições e competências estava "[...] coordenar as atividades repressivas das entidades oficiais ou não", "assessorar o Governo Federal" na matéria, "proceder a estudos, pesquisas e inquéritos" sobre a questão e 
"propor $[\ldots]$ as medidas que considerar oportunas na repressão do mal”. (BRASIL, 1935d, p. 2)

Durante o segundo semestre, sob coordenação do Itamaraty, diversos oficios foram trocados entre ministros, autoridades e demais burocratas para agregar as forças suficientes e apresentar a proposta do "Comitê" ao presidente. Ao Procurador Geral da Saúde Pública, por exemplo, foi solicitado que apresentasse um "[...] pequeno relatório escrito sobre o problema social das toxicomanias, apreciado pelo prisma das funções" que exercia, ou seja, pela ótica médica. (BRASIL, 1935e, p. 2) Ao Ministro da Agricultura, por outro lado, se requeria o auxílio "[...] principalmente na parte que diz respeito à cultura e possivel aproveitamento industrial de plantas nocivas, de efeitos entorpecentes". (BRASIL, 1935f, p. 1) Como se vê, cada repartição era convocada a participar com seus conhecimentos específicos e assim "tornar efetiva a existência legal" desse órgão, considerado "altamente humanitário e patriótico". (BRASIL, 1935g, p. 2)

Fundir controle social, humanitarismo e nacionalismo deveria ser a tônica do Comitê Central, segundo seus articuladores em 1935. O objetivo foi alcançado em abril do ano seguinte, quando o Decreto n. 780 de 28 de abril de 1936 deu existência legal ao órgão, recebendo o título de Comissão Nacional de Fiscalização de Entorpecentes (CNFE). A comissão passaria então a atuar oficialmente e isso significou basicamente duas coisas.

A primeira foi a consolidação da perspectiva médica sobre o uso psicoativo de drogas na postura assumida pelo Estado para encarar o fenômeno, visto que a CNFE era formada em sua maioria por membros dessa classe como seu presidente, o dr. Roberval Cordeiro de Farias, o representante do Ministério do Trabalho, dr. Décio Parreiras e o diretor do Sanató- 
Sonhos da diamba

rio Botafogo no Rio de Janeiro, o dr. Pedro Pernambuco Filho. A segunda foi o aparelhamento do Estado na questão: estava agora dotado de um órgão central dedicado exclusivamente à problemática do uso de drogas.

Apesar de todo esse investimento de diversas forças sociais que comungaram na repressão à maconha ao longo da década de 1930, aparentando certa unanimidade, a relação da planta Cannabis sativa com o Estado não deixou de possuir certa ambiguidade nesse período. Ao perceber essa ambiguidade velada, invisibilizada, será possível fazer uma ideia, ainda que limitada, da complexidade que envolveu a questão da maconha no Brasil no século XX.

Em 28 de julho de 1932, a Legação do Brasil em Cuba envia um ofício ao Itamaraty, solicitando informações sobre "[...] a cultura no Brasil da planta conhecida sob o nome de Hibiscus canabinnus e bem assim um pouco de sementes da referida planta”. (BRASIL, 1932a, p. 1, grifo do autor) O ministro solicitou as informações e as sementes ao Jardim Botânico do Rio de Janeiro. As sementes só foram conseguidas com o Instituto Agronômico de Campinas (IAC) em fevereiro de 1933, já as informações foram fornecidas rapidamente pelo Jardim Botânico. Segundo o seu diretor, o dr. Achilles Lisboa:

Esse vegetal, muito conhecido nas Índias como fornecedor de fibras celulósicas [...] tem sido encontrado nos Estados de Minas Gerais e Bahia. Várias tentativas de exploração comercial [...] foram feitas com essa planta. As experiências realizadas pelo Instituto Agronômico de Campinas deram resultados muito satisfatórios, tendo se obtido fibras de apreciável valor econômico. (BRASIL, 1932b, p. 1, grifo nosso)

Ao IAC também foram solicitadas informações, que o seu diretor alegou não poder fornecer, pois não possuía "[...] dados experimentais sobre a cultura do cânhamo brasileiro (Hibiscus 
cannabinus)". (BRASIL, 1933a, p. 1, grifo nosso) Esse ocorrido, apesar da brevidade dos documentos, nos diz algo.

Primeiro, é revelador, pois evidencia ter havido "várias tentativas de exploração comercial" de fibras de cânhamo no Brasil durante o início do século XX. Nas palavras do dr. Lisboa, a planta era encontrada naturalmente em "Minas Gerais e Bahia", mas explorada em São Paulo, por experiências levadas a cabo por um instituto estatal, obtendo "resultados satisfatórios", com fibras valiosas economicamente para a produção têxtil. O IAC, órgão apontado pelo diretor do Jardim Botânico como o responsável pelas pesquisas, surpreendeu e afirmou não ter "dados experimentais" para informar.

Mesmo assim sua resposta foi significativa: como autoridade empírica no caso, se referiu à planta como "cânhamo brasileiro". Ou seja, o Estado havia investido na criação de uma variedade brasileira de Cannabis. Entretanto, o empreendimento não parece ter tido uma vida muito longa, apesar do entusiasmo captado nas considerações do dr. Lisboa e não se tem mais informações sobre esse tipo de iniciativa oficial durante a República. E lá se iam, no dia 21 de março de 1933, 200 gramas de sementes de "cânhamo brasileiro" para florescer em Cuba, a pedido do seu Secretário da Agricultura, o general Eugenio Molinet. (BRASIL, 1933b)

Outra evidência dessa ambígua posição encontra-se em 1939. Em fevereiro, o diretor da Seção de Fiscalização do Exercício Profissional do Departamento Nacional de Saúde encaminhou à CNFE "Instruções para a execução do Decreto-Lei n. ${ }^{\circ}$ 891", a Lei de Fiscalização de Entorpecentes, aprovada no ano anterior. As "Instruções" visavam regulamentar o referido Decreto-Lei em seus detalhes e lhe dar funcionalidade. Na "Tabela A" encontra-se a maconha, aqui referida como "cânhamo - Cannabis sativa e variedade indica", entre as dezenove 
"substâncias entorpecentes em geral". (BRASIL, 1939e, p. 2) E na "Tabela D", que elenca a "Relação dos entorpecentes de existência obrigatória nas farmácias", encontram-se três dos seus derivados: o "extrato", o "extrato fluido" e a "tintura". (BRASIL, 1939e, p. 5, grifo nosso) O Brasil vinha importando essas substâncias da Alemanha, como mostra a "Estatística Trimestral de Importações e Exportações" enviada à Liga das Nações em 13 de julho de 1938, na qual está informada a compra de 10 quilogramas de "cânhamo indiano" e 42 quilogramas de suas "preparações (extratos, extratos fluidos e tintura)" durante o segundo trimestre do ano. (BRASIL, 1938c, p. 2-3)

Apesar de compor o rol de substâncias proscritas desde 1932, sendo proibido o cultivo da planta da qual é extraída, a maconha também era, sob a forma de preparações médicas, substância "de existência obrigatória nas farmácias". Sendo proibida qualquer forma de uso fora dos padrões da medicina científica, a droga e seus derivados eram legalmente importados para atender a necessidades dessa medicina. A mesma ciência que a condenava e estigmatizava seus usuários, reconhecia a sua aplicação como medicamento e impunha "quantidades mínimas" da substância para a "instalação de farmácias". (BRASIL, 1939e, p. 5) Ora, isso parece mostrar que a planta não era esse "mal" absoluto que se buscava consolidar perante a opinião pública: para o Estado, o "mal" dependia de como e quem a usasse.

Um caso ocorrido no Rio de Janeiro, no ano de 1941, pode ser exemplar nesse sentido. Com a palavra o desembargador Adelmar Tavares relator da Revisão Criminal n 767 :

O requerente foi, com Pedro C. G., preso em flagrante, quando em 29 de dezembro de 1941, na plataforma interna do Armazém 12 do Cais do Porto, sobre uma pilha de caixas de cerveja, manipulava cigarros de erva maconha. [...] O requerente de profissão 'consertador de caixas' foi 
condenado porque 'na posse e utilização de substância que figura expressamente no primeiro grupo das que a lei considera entorpecente', tendo sido surpreendido na manipulação de cigarros para viciados de Cannabis indica (artigo $1^{\circ}, \mathrm{n}^{\circ} \mathrm{XVI}$ do Decreto 891). Fabricando manualmente tais cigarros pra seu uso ou de terceiros, concorria conscientemente, animava, cooperava para a disseminação de um dos maiores flagelos da humanidade. (TAVARES, 1958, p. 375-376, grifo do autor)

Faltava pouco mais de dois dias para o ano de 1942 quando Raimundo e Pedro foram detidos pelos fiscais da polícia portuária no Rio de Janeiro e acusados de serem surpreendidos com 25 cigarros prontos e alguma quantidade de maconha. Estavam no Cais do Porto, onde trabalhavam e, como foi visto páginas atrás, portos e seus trabalhadores atraíam a atenção das autoridades nesse assunto.

Foram condenados pela $16^{\mathrm{a}}$ Vara Criminal da capital federal a um ano de reclusão e multa, no grau mínimo do que estabelecia a Lei de Fiscalização de Entorpecentes. Pedro apelou da sentença, mas esta foi confirmada pela Segunda Câmara. Raimundo, então, apelou pela revisão da pena para a última instância criminal:

Agora, pede o requerente revisão, dizendo que não tendo apelado, o Tribunal não apreciou a sentença em sua parte, e que o fato não se dera como contradição da prova. Refere que achou a maconha e se ter a 'posse momentânea' fosse crime, plantadores, químicos e farmacêuticos 'que pousam as mãos em maconha' também seriam criminosos. (TAVARES, 1958, p. 376, grifo do autor)

Como de praxe, ele negou as acusações, alegando que fora coagido pela polícia a assinar a confissão.

Segundo Raimundo ele "achou a maconha". Tal argumento não era de todo aleatório, poderia demonstrar que não havia intencionalidade da sua parte na ocasião e o livraria de 
algumas condutas criminalmente tipificadas, tais como guardar, ministrar, transportar, trazer consigo ou vender a droga. Porém, como visto, não colou. Ademais, o que se destaca é o argumento seguinte: em sua opinião, não era um criminoso, pois a "posse momentânea" da droga não era uma condição apenas sua, "químicos e farmacêuticos" também "pousam as mãos em maconha”. No seu entender, a lei deveria ser aplicada indistintamente: se médicos e cientistas a manipulam ou seriam todos criminosos, assim como ele era caracterizado, ou seriam todos inocentes, inclusive ele. Raimundo, então, evidencia que a lei não era igualmente aplicada a todos e discorda.

Porém, o relator - o desembargador Adelmar Tavares - tinha outra opinião. Baseando-se no artigo 281 do Código Penal de 1940, indeferiu o pedido e seus colegas desembargadores o seguiram. Para a autoridade "o ato praticado pelo requerente infringiu abertamente a lei" e, dessa forma, "a sentença aplicou pena justa”. Na visão do jurista:

Não tem, porém, procedência qualquer das alegações. O pedido vem destituído de qualquer elemento de credibilidade [...]. Só a podem utilizar as pessoas devidamente autorizadas, com as formalidades legais, e na forma por Leis estabelecida. Tudo está na lei regulado. Os que podem lidar com entorpecentes só podem fazê-lo na forma pela qual prescreve a lei. (TAVARES, 1958, p. 376)

As alegações do acusado foram deslegitimadas, julgadas "destituídas de credibilidade" e "sem procedência". Se Raimundo entendia que a lei deveria ser a mesma para todos, Tavares discordava: a lei definia "os que podem lidar com entorpecentes" e "os que não podem", as "pessoas devidamente autorizadas" e as "desautorizadas", para essas o resultado deveria ser a cadeia. Raimundo foi incluído nesse segundo grupo, pois "de profissão consertador de caixas" do porto e sem "as formalidades 
legais" para "lidar com entorpecentes". Para o desembargador, ao "pousar as mãos em maconha", diferentemente dos "químicos e farmacêuticos", infringia a lei, pois esta não lhe autorizava, tornava-se um criminoso e concorria conscientemente para a disseminação de um dos maiores flagelos da humanidade. Em suas mãos a maconha era considerada um "mal".

Os julgadores evocaram diferentes normas para condenar os réus: em primeira instância, o juiz da $16^{\text {a }}$ Vara Criminal se apoiou no artigo 33 do Decreto-Lei n. 891 de 1938, que definia pena de um a cinco anos de prisão e multa, interpretação seguida pela Segunda Câmara; o desembargador que julgou o pedido de apelação em 1943, por sua vez, se apoiou no Código Penal de 1940, diploma que passou a vigorar no ano anterior e adotou a mesma pena do decreto de 1938.

Não há certeza, entretanto, se a maconha apreendida com eles de fato lhes pertencia nem se foram ou não coagidos pelos policiais a assinar a confissão e se incriminarem. Também não se pode confirmar se a quantidade foi exatamente aqueles 25 cigarros prontos, como também não se a droga era para seu uso pessoal ou para comercializar. Em todo caso, é possivel perceber que o problema estava em quem "manipulava" a "substância entorpecente" e, além disso, que diferentes normas jurídicas poderiam ser combinadas pelas autoridades ao julgar.

Os casos acima demonstram, em linhas gerais, as características e ambiguidades do proibicionismo brasileiro das drogas consolidado ao longo da década de 1930. Esse período pode ser considerado como "a década das proibições" ou "década do proibicionismo" no Brasil pelo visível esforço controlador em relação às drogas em geral, e à maconha em específico, mas guarda as suas contradições reveladoras. Para além dos discursos humanitários e médicos-jurídicos que emergiam sobre a 
maconha, levando ao crescimento da opinião pública condenatória que desembocou na naturalização do "problema", outras questões e interesses poderiam orientar outras posturas desse mesmo Estado em relação à planta.

$\mathrm{Na}$ década seguinte o proibicionismo brasileiro beneficiou-se do aparelhamento e especialização desse momento de formação, possibilitando a realização de novas atividades no campo da repressão à maconha, como a expansão da sua rede institucional. A CNFE, por exemplo, funcionaria mais efetivamente na década de 1940, depois da criação das diversas Cefe.

As Cefe foram instituídas com o Decreto-Lei n. 891 de 1938, que em seu Art. 45 determinava:

Nos Estados e no Território do Acre serão organizadas Comissões estaduais nos moldes da Comissão Nacional com jurisdição nos respectivos territórios, as quais se entenderão diretamente com a Comissão Nacional, a que ficam subordinadas e, excepcionalmente, nos casos de urgência, com as dos Estados vizinhos. (BRASIL, 1938d, p. 238)

Deveriam compor as Cefe o diretor do Serviço Sanitário Estadual, o chefe da segurança pública, um representante do Departamento Nacional de Saúde (DNS), designado pelo respectivo diretor, o Procurador Seccional da República e um representante da classe médica da capital do estado, escolhido em lista tríplice apresentada pelo Serviço Sanitário Estadual à CNFE.

Com as Cefe, se buscava completar a rede de intervenção do Estado nacional na questão. Tomando como base a estrutura da CNFE, as respectivas estaduais estavam subordinadas ao órgão central, como define o Art. 45. Os membros das Cefe deveriam ser em sua maioria médicos, tanto de dentro como de fora do poder público: dos cinco cargos da comissão, três esta- 
vam destinados a eles. Os outros dois, em geral, eram ocupados por juristas e até mesmo militares, como no caso de alguns chefes de segurança pública dos estados.

Como se percebe, a visão do uso psicoativo de drogas como uma toxicomania e como um crime contra a segurança da sociedade, dos usuários como doentes e mais ainda como criminosos e a repressão policial como forma padrão de lidar com esse consumo, que definiriam a atuação das comissões estaduais, estão profundamente conectados com essa dimensão autoritária do período Vargas. Com as Cefes o Estado buscava cercar o problema em vários níveis, tendo um órgão central coordenador e órgãos locais, assim como, em diversas frentes, medicina, direito e segurança.

Na Bahia, as primeiras movimentações para a formação da comissão estadual ocorreram em 1939. No dia 7 de junho desse ano, foram nomeados os primeiros membros, eram eles: César Araújo - diretor do Departamento Estadual de Saúde Pública, Urbano Pedral Sampaio - chefe de Polícia, Raul Alves de Souza - procurador da República, e João Ignácio de Mendonça - representante dos médicos. De início, não houve representante do DNS na comissão estadual. Dos quatro, dois eram bacharéis em direito: Raul Alves e Urbano Sampaio, e dois médicos: César Araújo e João Mendonça. Nesse momento foi intitulada "Subcomissão de Fiscalização de Entorpecentes da Bahia" e não parece ter tido muita operacionalidade até 1943. (BRASIL, 1939f)

Como dito algumas linhas atrás, foi na década de 1940 que os órgãos de controle e repressão ao uso psicoativo das drogas no Brasil demonstraram uma forte atividade e conexão. Foram viagens de inspeção e intercâmbio, reuniões, conferências e produção de textos científicos que evidenciam o desenvolvimento do proibicionismo brasileiro, mas também evidenciam 
os limites e dificuldades do projeto impostos pela burocracia e pela morosidade estatal.

Dentro desse processo e como um foco privilegiado, motivador dessa mobilização, está a maconha. Ela foi a droga que redundou, ao logo dos anos 1940, em duas visitas do presidente da CNFE à Bahia, em diversos estudos científicos elaborados por médicos ligados à CNFE ou à Cefe baiana, como o médico João Mendonça, e no Convênio Interestadual da Maconha, realizado em Salvador.

Em 1941 Roberval Cordeiro de Farias chegava pela primeira vez à Bahia em "missão oficial”. (BRASIL, 1941) Pela sua importância como presidente da CNFE, já havia viajado para estudar o combate às drogas em países da Europa e da América do Sul nos anos anteriores. ${ }^{11}$ Parte de um esforço maior da CNFE, a viagem era o primeiro ponto de um programa que objetivava analisar o "problema da maconha" nas regiões Norte e Nordeste. Talvez devido à incipiência da Cefe baiana naquele ano, a viagem não foi bem documentada. A única informação revela que dessa "missão oficial" resultou um artigo científico de autoria de Farias intitulado "Campanha contra o uso da maconha no Norte do Brasil", sendo solicitada a reprodução de mil cópias à Divisão de Material da Secretaria de Estado das Relações Exteriores. (BRASIL, 1943b) Contudo nenhuma cópia foi encontrada.

A segunda visita do presidente da CNFE à Bahia, em novembro de 1943, também integrou um esforço mais amplo, mais uma vez voltado para os estados da região Nordeste, desta vez Bahia, Sergipe e Alagoas. (BRASIL, 1943c)

11 Em 1939, o presidente da CNFE viajou em "missão oficial" para a Alemanha e em 1940 viajou ao Uruguai e à Argentina, em ambas as ocasiões afirmou que seu objetivo era "estudar a organização e a fiscalização da indústria farmacêutica e o comércio de entorpecentes”. (BRASIL, 1940a) 
Essa "inspeção", "visando o problema do comércio e uso da maconha" foi muito melhor registrada, nos legando uma cobertura entusiasmada dos jornais de Salvador. Importante analisar o que falaram os jornais soteropolitanos e o que falou a própria autoridade sobre aquela empreitada de combate à maconha no início da década de 1940.

Três periódicos noticiaram a presença da autoridade na Bahia em novembro de 1943: O Imparcial, O Estado da Bahia e A Tarde. O Imparcial foi o mais sucinto e apenas pontuou que o mesmo havia "concertado providências" em colaboração com autoridades estaduais "relativamente à repressão ao uso de tóxicos" sem mencionar quais. (REPRESSÃO, 1943, p. 4) $A$ Tarde foi mais extenso na sua reportagem. Mesmo dando mais destaque à repressão ao álcool na entrevista com o médico, afirmou que o doutor defendia "medidas ainda mais severas de repressão à maconha”. (ÁLCOOL, 1943, p. 2)

O periódico que mais se prolongou sobre o "problema da maconha" foi O Estado da Bahia. Com a matéria discutiu a questão em diversas dimensões. Nas palavras de Roberval Farias:

O principal problema hoje em dia que preocupa a Comissão de Fiscalização de Entorpecentes é o uso da maconha. [...] Os principais focos são os estados de Maranhão e Piauí, ao norte e no vale do São Francisco, Alagoas e Sergipe [...]. Na Bahia, segundo algumas investigações, é reduzido o uso da maconha e só praticado por elementos frequentadores de sessões de 'magia negra' e 'macumbas'. (MEDIDAS, 1943, p. 3, grifo nosso)

A autoridade ainda explicou que estava na Bahia para se "articular" com as autoridades estaduais, "[...] afim de que mais eficiente possa ser o combate a esse abominável vício". (MEDIDAS, 1943, p. 3) 
Sonhos da diamba

Os três jornais chamaram a atenção para a importância da repressão às drogas. Em todos três também ficou clara a dimensão estratégica da visita do presidente da CNFE: veio ele se "articular" com as autoridades locais em prol de "medidas mais severas" e um combate "mais eficiente", sobretudo dos usos da maconha. Em todos, ela é considerada uma "toxicomania", um vício "tão nocivo como o álcool e a cocaína".

É na entrevista do presidente da CNFE, um médico agente do órgão oficial de combate às drogas, para o jornal O Estado da Bahia que se pode apreender com mais nitidez a perspectiva sobre a maconha decorrente da colaboração entre medicina e Estado à época. Por meio da sua fala, sabe-se que o uso psicoativo da maconha era considerado pela CNFE o "principal problema" na questão das "toxicomanias", vê-se atualizada mais uma vez a associação aos estados do Norte e Nordeste como "principais focos" de tráfico e consumo da erva e são captados ecos do discurso fundador de Rodrigues Dória, definindo maconha como um hábito de negros, já que, na época, o termo "macumba" era sinônimo de práticas religiosas de afro-brasileiros.

Neste ponto, sua opinião se torna particularmente interessante pelo fato de que acusa diretamente o candomblé, para ele "magia negra" e "macumba", de possuir uma intrinseca relação com a maconha. Esse ponto será melhor abordado mais adiante, porém cabe aqui um comentário. O presidente da CNFE, com certeza, fazia coro às observações de Rodrigues Dória, outro médico que já havia traçado essa relação décadas atrás, e poderia não estar equivocado ao apontá-la, haja vista que alguns literatos, folcloristas e antropólogos também a notaram. Entretanto, ele a insere numa perspectiva preconceituosa, vide o emprego dos termos de forma pejorativa para se referir à religião, e criminalizadora, pois considerava seu uso psicoativo um "uso ilícito", não considerando os significados 
que viesse a ter no contexto religioso. Pelo visto, antigos mecanismos de estigmatização e controle da população afro-brasileira ainda podiam ser evocados e associados à perspectiva condenatória da maconha em meados do século XX.

Três anos após a segunda "visita de inspeção" de Roberval Cordeiro de Farias à Bahia, autoridades representantes de quatro estados da região Nordeste se encontraram em Salvador, entre os dias 16 e 18 de dezembro de 1946, no "Convênio para estudo dos problemas relacionados com o uso e o comércio da maconha". (BAHIA, 1946, p. 1) Nesses três dias, no Salão de Conferências da Secretaria de Educação e Saúde do Estado da Bahia, buscaram assento alguns senhores ilustres do aparelho de Estado local: entre eles, o Interventor Federal, general Cândido Caldas, o delegado de Jogos e Costumes de Salvador, Orlando Imbassahy da Silva, Thales de Azevedo, o Secretário de Educação e Saúde, Odilon Machado, e o de segurança pública, major Wolmar Carneiro da Cunha. Esse último era membro da Cefe baiana, juntamente com os médicos também presentes Álvaro Garcia Rosa, Antônio Chrisipo de Aguiar, João Ignácio de Mendonça e Álvaro Rocha da França.

Além das autoridades baianas, se faziam presentes nomes importantes do proibicionismo da maconha no Brasil: os médicos Garcia Moreno, diretor do Departamento de Saúde de Sergipe, Cláudio Magalhães da Silveira, representante da Cefe de Alagoas, e Eleyson Cardoso, representante do presidente da CNFE e da Cefe de Pernambuco. Eram os representantes dos estados aos quais se atribuíam os "centros de produção do nordeste". (CARDOSO, 1958a, p. 165) Os seus governos, então, decidiram se empenhar na construção de uma campanha conjunta contra os usos da erva e o Convênio Interestadual da Maconha de 1946 deveria ser o ponto de partida. 
O convênio teve como objetivo geral desenvolver um mecanismo de repressão ao "uso ilícito" da maconha através de uma "colaboração mais estreita entre as Cefe".

Mas se desdobrou em dois sentidos: definir as medidas de repressão e controle conjuntas e aperfeiçoar os instrumentos burocráticos na matéria. No primeiro sentido estão as sugestões apresentadas no relatório produzido pelo dr. João Mendonça, membro da Cefe baiana, sistematizadas em dezenove "Conclusões" que foram aprovadas na $3^{a}$ Sessão do Convênio, no dia 18 de dezembro. No segundo, foram discutidas formas de facilitar a destruição das plantações de maconha encontradas pelas autoridades estaduais.

As "Conclusões" foram definidas ao longo dos três dias de debates e alguns pontos mereceram a atenção dos participantes, a exemplo da "[...] vigilância especial dos delinquentes contra a propriedade", o "intercâmbio obrigatório" entre as comissões dos quatro estados, a "padronização dos estudos" sobre a maconha e a "[...] divulgação educativa e selecionada dos perigos das toxicomanias". Entre elas, uma se destaca, a conclusão n'. 18: "Matrícula dos cultos afro-brasileiros [nas Delegacias de Jogos e Costumes estaduais] e intercâmbio policial-médico de ordem educativo-higiênica". (CARDOSO, 1958, p. 173-174) A proposição estava ligada à exposição de dados estatísticos feita por João Mendonça, que afirmava haver entre os usuários de maconha "predominância de pretos e mulatos".

Essas sugestões apontam para um determinado perfil de usuário de maconha encontrado entre as classes subalternas. Não por acaso, as teses de Rodrigues Dória são largamente mencionadas nas considerações feitas pelo representante da CNFE, Eleyson Cardoso. Adicionada a fala de Roberval Cordeiro de Farias ao jornal O Estado da Bahia três anos antes, afirmando que seu uso no estado era restrito às sessões de 
candomblé, percebe-se uma das bases sobre as quais se sustentava o projeto de repressão interestadual.

A conclusão da "predominância de pretos e mulatos" transformava esses grupos no alvo por excelência das ações policiais, estendendo-se a suspeita às práticas religiosas na qual eram a maioria. E se os negros eram vistos como os maiores usuários de maconha, as autoridades concluíram que uma religião composta por eles deveria ser vigiada de perto por um "intercâmbio policial-médico" para coibir qualquer forma de uso. Considerando-os "ilicitos" mais uma vez negligenciam os significados rituais que pudessem ter e mantêm válida uma justificativa para a ação violenta do Estado sobre seu modo de vida.

Outro ponto que atraiu os esforços das autoridades presentes ao convênio em 1946 foi o fim de um entrave legal que dificultava a ação dos órgãos de combate à maconha nos estados. Esse entrave encontrava-se no Decreto-Lei n. ${ }^{\circ} 891$ de 1938, que exigia a "direção técnica" de um representante do Ministério da Agricultura para que fossem devidamente destruídas as plantações de maconha. Porém, as autoridades dos quatro estados concordaram com Eleyson Cardoso (1958, p. 168) no intuito de promover uma "lei supletiva ao Decreto-Lei n. 891 ou o estudo de sua reforma" já que nem todos os estados possuiam aquele representante. A solução aceita foi apresentada pelo médico Benício Gomes, membro da Cefe baiana: a "inclusão nos dispositivos legais de uma autorização às Secretarias de Agricultura, nos estados, para representarem o Ministério". (CARDOSO, 1958, p. 172) Esta sugestão deveria ser encaminhada à CNFE para a apreciação do presidente Vargas, mas não se sabe se assim ocorreu. Contudo, o episódio não deixa de ser significativo.

A iniciativa buscava adaptar a lei ao "[...] desenvolvimento da ação das comissões estaduais na campanha contra a maco- 
Sonhos da diamba

nha", como afirmava Eleyson Cardoso (1958, p. 168). Quando foi aprovado, o Decreto-Lei n. 891 de 1938 também determinava a criação das Cefe, que só vieram a ter uma ação mais eficaz durante a década de 1940, após serem construídas com considerável êxito as bases legais do proibicionismo brasileiro. A realidade havia mudado com a instalação de diversas comissões estaduais e esses órgãos agora buscavam uma maior autonomia perante órgãos centrais, como a CNFE. Se, por um lado, promoviam um intercâmbio institucional cada vez maior, ampliando o controle estatal, por outro, ainda precisavam reformular as suas próprias regras, evidenciando que a centralização colocava limites ao pleno desenvolvimento da "campanha contra a maconha".

Acompanhando o processo de formação e consolidação do proibicionismo brasileiro durante as décadas de 1930 e 1940 , percebeu-se que a maconha teve um capítulo exclusivo. Primeiro foi considerada um "problema médico" e tornou-se objeto de um discurso condenatório que viu numa "origem africana" e no seu uso popular a "vingança do vencido" e um "vício degenerativo" causador de "loucura criminosa". Contudo, uma indiferença de quase vinte anos demonstrou que não bastava apenas a vontade de uma classe para instituir o "problema da maconha", era preciso uma conjuntura social sensivel a esse apelo médico. Foi nas décadas de 1930 e 1940 que os usos não científicos da maconha passaram a ser considerados ilícitos, considerados crime.

Nos anos 1930, a convergência de um movimento transnacional de "combate às drogas", capitaneado pela Liga das Nações e pelos Estados Unidos, com as demandas internas de controle social do governo Vargas, gerou um aparato legal que alcançou maior desenvolvimento na década seguinte. Leis, instituições e intercâmbios foram estabelecidos durante esses 
anos, tendo a maconha um foco privilegiado. Entretanto, a planta e seus derivados se relacionaram de forma ambígua com o Estado: uma variedade nacional de cânhamo foi desenvolvida e exportada para outro país, assim como medicamentos dela extraídos eram obrigatórios em farmácias.

Demonstrar o complexo jogo de poder e os diversos agentes sociais envolvidos na construção do "problema da maconha" durante a primeira metade do século XX no Brasil, evidenciando que esse processo foi transformado em mecanismo de controle de classe e preconceito racial, foi fundamental para o nosso próximo passo: recompor a experiência histórica dos grupos sociais acusados de fazerem "uso ilícito" da maconha no Brasil e, principalmente, na Bahia. Agora é a vez de ouvir a história pela ótica dos subalternos. 